American University Washington College of Law

Digital Commons @ American University Washington College of

Law

Articles in Law Reviews \& Other Academic Journals

Scholarship \& Research

2009

Sit Down and Count the Cost: A Framework for Constitutionally

Enforcing the 501(C)(3) Campaign Intervention Ban

Benjamin Leff

Follow this and additional works at: https://digitalcommons.wcl.american.edu/facsch_lawrev

Part of the Election Law Commons, First Amendment Commons, and the Nonprofit Organizations Law Commons 


\title{
"SIT DOWN AND COUNT THE COST": A FRAMEWORK FOR CONSTITUTIONALLY ENFORCING THE 501(C)(3) CAMPAIGN INTERVENTION BAN
}

\author{
Benjamin M. Leff
}

\begin{abstract}
Section 501(c)(3) of the Internal Revenue Code (Code) prohibits charities from intervening in a political campaign for or against a candidate for public office. The Internal Revenue Service (Service) currently interprets the campaign-intervention ban to absolutely prevent charities from communicating their views on candidates, even if such communications are completely financed by non-501(c)(3) affiliates.

This article argues that the current Service enforcement paradigm is unconstitutional because it exceeds the government interest in preventing tax-deductible donations to be used for campaignintervention. A constitutional interpretation exists under the current statutory framework, but it would require the Service to shift its focus exclusively to campaign-intervention-related expenditures. The Service could compel 501(c)(3) organizations to make all expenditures through a non-501(c)(3) affiliate using funds that were raised on a nondeductible basis, or receive reimbursement from a non-501(c)(3) for all such expenditures.

Enforcement of the ban under the proposed "expenditure" paradigm requires an ability to "value" campaign-intervention speech to provide a means for a non-501(c)(3) affiliate to pay for or reimburse

- Visiting Assistant Professor, Harvard Law School. A.B., Oberlin College; A.M., University of Chicago; J.D., Yale Law School. The author would like to thank Ellen Aprill, William Forbath, David Gamage, Mark Gergen, Michael Hatfield, Calvin Johnson, Louis Kaplow, Kurt Lash, Lisa Leff, Daniel Markovits, Lloyd Mayer, Katherine Pratt, Theodore Seto, and the students at the Loyola of LA Law School Tax Policy Colloquium for their invaluable comments.
\end{abstract}


the cost of such speech. This article evaluates competing valuation theories, and finds that campaign-intervention speech that communicates a charity's endorsement of a candidate (whether official or unofficial) may "cost" more than commentators have previously considered. Because an endorsement implicates the "goodwill" that an organization has built up using tax-deductible contributions, it may well be appropriate to take the cost of developing that goodwill into account in determining the cost of the campaign-intervention communication. This article proposes some guidelines for valuing the speech of charities, taking the cost of goodwill into account. It concludes that an "expenditure" paradigm that adequately valued the speech of charities may be more enforceable, and therefore more effective at limiting excessive or abusive campaign-intervention speech by charities, while staying within constitutional parameters.

\section{TABLE OF CONTENTS}

I. INTRODUCTION

II. BURDENS AND BENEFITS CONTAINED IN SECTION 501(C)(3) OF THE CODE 682

III. The CONSTITUTIONAL NECESSITY OF "AfFILIATE ORGANIZATIONS" 685

IV. TWO DISTINCT MODES OF ANALYSIS: ATTRIBUTION AND EXPENDITURE. 696

V. "VALUATION" UNDER AN EXPENDITURE PARADIGM 702

A. Current Proposals Insufficiently Address Expenditure Equity: De Minimus Solutions and Marginal Cost Theories.

B. A Sufficient Theory Must Account for Allocation of Expenditures that Advance Campaign-Intervention Objectives. 708

1. Allocation of Costs 708

2. The General Problem of "Capital Assets" 711

3. The Allocation of the Cost of an Organization's "Credibility" 
VI. PROPOSED SOLUTIONS: MODELS FOR AN EXPENDITURE

PARADIGM

A. Allocation Using the Methods Approved Under

Treasury Regulations 1.162-28.

B. Allocation Using the Lump-Sum Safe Harbor Method .... 721

VII. IS THE LUMP-SUM SAFE HARBOR JUSTIFIED? 723

A. The Lump-Sum Safe Harbor Method Distorts

Equitable Considerations

B. The Lump-Sum Safe Harbor Method is Arbitrary 725

C. If There Is No Compelling Valuation Method, Then the Service's Complete Ban Is Constitutional. 726

VIII. CONCLUSION: WHY THE PROPOSED EXPENDITURE PARADIGM IS GOOD POLICY 728

\section{INTRODUCTION}

The Internal Revenue Code (Code) provides benefits to charitable organizations, but it also imposes burdens. ${ }^{1}$ One such burden is that a section 501(c)(3) organization may not "participate in, or intervene in (including the publishing or distributing of statements), any political campaign on behalf of (or in opposition to) any candidate for public office" (hereinafter the Campaign Intervention Ban or Ban). ${ }^{2}$

The Campaign Intervention Ban has been the subject of considerable attention from both critics and supporters over its fiftyodd-year history. ${ }^{3}$ When the overheated rhetoric is pared away, it

"In general, I have used the terms "charity," "charitable organization," and "501(c)(3) organization" interchangeably to mean an organization that is described in section 501(c)(3) of the Internal Revenue Code of 1986, as amended (Code), and therefore potentially or actually exempt from tax under section 501(a) and authorized to receive tax-deductible contributions under section 170 (c)(3) of the Code.

${ }^{2}$ I.R.C. $\S 501(\mathrm{c})(3)$. See also, I.R.C. $\$ 170(\mathrm{c})(2)(\mathrm{D})$; Treas. Reg. $\$ 1.501(\mathrm{c})(3)-$ 1(c)(3)(iii) (2008). The subject of this article is the Campaign Intervention Ban, which generally prohibits charities from attempting to affect the outcome of an election. Attempts by charities to affect the passage of legislation (commonly called "lobbying") are separately restricted under section 501(c)(3), but the lobbying restriction should not be confused with the Campaign Intervention Ban.

${ }^{3}$ See infra notes 8-9 and accompanying text discussing critics and proponents of the Ban. As of the writing of this article, the most recent attack on the ban has been a day of protest called "Pulpit Freedom Day," in which thirty-three pastors openly 
becomes clear that the most coherent understanding of the Ban is that it attempts to balance two competing governmental interests. On the one hand, the provision reflects the government's interest in avoiding the creation of a loophole in the funding of political campaigns. Since 501(c)(3) organizations receive contributions on a tax-deductible basis - the argument goes - the ability to make use of such contributions to influence the outcome of an election would constitute an unfair advantage in favor of charities (or their donors) over other taxpayers. The Ban, then, is often thought of as an attempt by Congress to prevent a government "subsidy" from being used for partisan political purposes. $^{4}$ In this article, I call this governmental interest "expenditure equity," because it reflects the government's interest in treating all taxpayers alike when they seek to use their funds to influence the outcome of an election. ${ }^{5}$

On the other hand, the First Amendment of the U.S. Constitution, and the jurisprudence developed to interpret it, reflects an interest in ensuring certain speech rights, including the rights of organizations to express their opinions about a candidate's qualifications for office. If the Ban is interpreted in such a way as to place unjustified or excessive burdens on an organization that wishes to engage in protected speech, then such an interpretation conflicts with these free speech values enshrined in the First Amendment. ${ }^{6}$ The Internal Revenue Service's (Service's) current regulatory paradigm holds that if an activity communicates an opinion about a candidate

defied the Ban by endorsing presidential candidates from the pulpit. See, e.g., Laurie Goodstein, Ministers to Defy I.R.S. by Endorsing Candidates, N.Y. TimEs, Sept. 26, 2008, at A20.

${ }^{4}$ See Regan v. Taxation With Representation of Washington, 461 U.S. 540, 544 (1983). See also Anne Berrill Carroll, Religion, Politics and the IRS: Defining the Limits of Tax Law Controls on Political Expression by Churches, 76 MARQ. L. REV. 217,251 (1992), who notes that refusing to permit a governmental subsidy to be used for partisan political purposes dates back at least as far as Slee v. Commissioner, 42 F.2d 184, 185 (2d Cir. 1930), in which Judge Learned Hand stated that "[c]ontroversies of [a partisan political] sort must be conducted without public subvention; the Treasury stands aside from them."

5 The fact that expenditure equity is the only coherent justification of the Ban is not to say that it was necessarily the purpose that motivated Congress as a matter of history. For a historical discussion of the enactment of the Ban see Oliver A. Houck, On the Limits of Charity: Lobbying, Litigation, and Electoral Politics by Charitable Organizations Under the Internal Revenue Code and Related Laws, 69 BROOK. L. ReV. 1, 16-29 (2003); Patrick L. O'Daniel, More Honored in the Breach: A Historical Perspective of the Permeable IRS Prohibition on Campaigning by Churches, 42 B.C. L. REV. 733 (2001).

${ }^{6}$ See discussion infra Part III. 
that can be attributed to a 501(c)(3) organization, then that activity is prohibited by the Ban. ${ }^{7}$ The only option provided to 501(c)(3) organizations that want to communicate their own views on the qualifications of candidates is to give up their filing status and forfeit their right to receive tax-deductible contributions for any purpose. This article argues in Parts III and IV that the Service's current interpretation of the Ban likely exceeds permissible constitutional bounds.

Some commentators argue that the Service should continue (or begin) vigorous enforcement of the Ban. ${ }^{8}$ Others have proposed solutions to resolve the existing clash between constitutional concerns and the government's interest in expenditure equity, usually proposing some limited exemption for certain types of

7 The Treasury has defined the activities prohibited to include, "the making of oral statements on behalf of or in opposition to such a candidate." Treas. Reg. $\S$ 1.501(c)(3)-1(c)(3)(iii) (2008). An Internal Revenue Service (Service) representative has amplified this interpretation as follows: "public statements of position (verbal or written) made by or on behalf of the organization in favor of or in opposition to any candidate for public office violate the prohibition against political campaign intervention." Hearing on Review of Internal Revenue Code Section 501(c)(3) Requirements for Religious Organizations Before the S. Comm. on Oversight of the H. Comm. on Ways and Means, 107th Cong. (May 14, 2002) (testimony of Steven T. Miller, Dir., Exempt Orgs., I.R.S.) [hereinafter Miller, Hearings]; see also, Rev. Rul. 2007-41, 2007-1 C.B. 1421, discussed infra at notes 73-82 and accompanying text. While the Service absolutely prohibits communications that reflect a charity's own views about a candidate, Service guidance attempts to create the opportunity for individuals associated with charities to make known their personal views on candidates and for organizations affiliated with charities to make known their views on candidates (so long as they are sufficiently independent of the charity).

8 See Donald B. Tobin, Political Campaigning by Churches and Charities: Hazardous for 501(c)(3)s, Dangerous for Democracy, 95 GEO. L.J. 1313, 1317 (2007) (arguing that permitting churches to engage in campaign intervention "would have grave consequences for our democratic system of governance"); see also Benjamin S. De Leon, Rendering a Taxing New Tide on IRC 501(c)(3): The Constitutional Implications of H.R. 2357 and Alternatives for Increased Political Freedom in Houses of Worship, 23 REV. LITIG. 691, 694 (2004) ("the imposition of the political activity prohibition should remain as it currently is written in the Internal Revenue Code"); Vaughn E. James, Reaping Where They Have Not Sowed: Have American Churches Failed to Satisfy the Requirements for the Religious Tax Exemption?, 43 CATH. LAw. 29, 78 (2004) (arguing that "[w] hat the country needs [is] strict enforcement by the Service of the existing laws"); Ann M. Murphy, Campaign Signs and the Collection Plate - Never the Twain Shall Meet?, 1 PITT. TAX REV. 35, 37 (2003) (arguing that "it is inadvisable and dangerous to allow churches and other houses of worship to campaign for candidates and participate in politics"). 
communications for certain 501(c)(3) organizations. ${ }^{9}$ These proposals often apply only to churches. ${ }^{10}$ Legislation has been proposed. ${ }^{11}$ But

${ }^{9}$ See Erik J. Ablin, The Price of Not Rendering to Caesar: Restrictions on Church Participation in Political Campaigns, 13 Notre Dame J.L. ETHICS \& PUB. PoL'y 541, 559 (1999); Johnny Rex Buckles, Is the Ban on Participation in Political Campaigns By Charities Essential to Their Vitality and Democracy? A Reply to Professor Tobin, 42 U. RICH. L. REV. 1057 (2008) [hereinafter Buckles, Reply]; Johnny Rex Buckles, Not Even a Peep? The Regulation of Political Campaign Activity By Charities Through Federal Tax Law, 75 U. CIN. L. REV. 1071, 1098 (2007) [hereinafter Buckles, Peep] ("the charitable sector has a legitimate political voice that federal income tax law should not substantially silence"); Laura Brown Chisolm, Politics and Charity: A Proposal for Peaceful Coexistence, 58 GEO. WASH. L. REV. 308 (1990) (proposing that the Ban be limited to so-called "express advocacy" communications under campaign finance law); Alan L. Feld, Rendering Unto Caesar or Electioneering for Caesar? Loss of Church Tax Exemption for Participation in Electoral Politics, 42 B.C. L. REV. 931, 939 (2001) ("[1]iteral enforcement of the provision seems unpalatable"); Vaughn E. James, The African American Church, Political Activity, and Tax Exemption, 37 SETON Hall L. Rev. 371, 410 (2007) (proposing that small churches be permitted to engage in campaign intervention using funds raised for that purpose, so long as they refrain from endorsing candidates from the pulpit or permitting candidates to campaign from the pulpit); Chris Kemmitt, RFRA, Churches and the IRS: Reconsidering the Legal Boundaries of Church Activity in the Political Sphere, 43 HARV. J. ON LEGIS. 145, 179 (2006) (proposing that churches be permitted to engage in campaign intervention speech, so long as no "tax-exempt money" is spent on it); Joseph S. Klapach, Thou Shalt Not Politic: A Principled Approach to Section 501(c)(3)'s Prohibition on Political Campaign Activity, 84 CORnell L. REV. 504, 540 (1999) (arguing that the Ban should not apply to any 501(c)(3) organization "when activity is peripheral to the furtherance of the organization's legitimate exempt function"); Allan J. Samansky, Tax Consequences When Churches Participate in Political Campaigns, 5 GEO. J.L. \& PUB. POL'Y 145, 150 (2007); ("Involvement by churches in campaigns should be an effective counterweight to moneyed interests that try to influence the voting public"); Jennifer M. Smith, Morse Code, Da Vinci Code, Tax Code and... Churches: An Historical and Constitutional Analysis of Why Section 501(c)(3) Does Not Apply to Churches, 23 J.L. $\&$ POL. 41, 43 (2007) (arguing that churches should be completely exempt from the Ban); Mark Totten, The Politics of Faith: Rethinking the Prohibition on Political Campaign Intervention, 18 STAN. L. \& POL'Y REV. 298, 314-15, 321 (2007) (proposing that because of the unique character of faith, Congress should amend the Code to permit oral communications at church gatherings); Deborah J. Zimmerman, Branch Ministries, Inc. v. Rossotti: First Amendment Considerations to Loss of Tax Exemption, 30 N. KY. L. REV. 249, 269-73 (2003) (describing various proposed solutions).

${ }^{10}$ I attempt to use the term "church" in this article in generally the same way it is used in the Code, to encompass any entity organized and operated for worship and religious observance, and not just houses of Christian worship. See, e.g., I.R.C. $\$ 170(\mathrm{~b})(1)(\mathrm{A})(\mathrm{i})$. The definition of "church" for the purposes of the Code is a complicated matter, see Samansky, supra note 9, at n.1, but these definitional issues do not affect the discussion here. 
there is something of a "ships passing in the night" quality to this debate. Proponents of the Ban champion enforcement in order to avoid government subsidization of campaign intervention by charities. ${ }^{12}$ They argue that the government's interest in expenditure equity justifies enforcement of the Ban, but they then propose enforcement paradigms (like the Service's) that exceed the requirements of expenditure equity. Critics of the Ban concede the government's interest in expenditure equity, but argue that speech or religious liberty rights trump it, and warrant at least some limited subsidization. ${ }^{13}$

In contrast to the solutions proposed in the past, this article attempts to develop an enforcement paradigm that fully serves the interests of expenditure equity, while fully acknowledging the importance of the speech rights involved. This enforcement paradigm necessarily focuses on funds - prohibiting a charity from using funds raised on a tax-deductible basis for campaign-intervention purposes. Because of its focus on funds, I have called this proposed paradigm an "expenditure" paradigm, as opposed to the Service's current "attribution" paradigm. ${ }^{14}$ This expenditure paradigm is an attempt to

${ }^{11}$ For example, H.R. 2275, 110th Cong. (2007) (repealing the Campaign Intervention Ban); Religious Freedom Act of 2007, S. 178, 110th Cong. (2007) (permitting churches to engage in campaign intervention "in the theological or philosophical context of such organization"); Religious Freedom Act of 2006, S. 3957, 109th Cong. (2006) (same); Houses of Worship Free Speech Restoration Act of 2005, H.R. 235, 109th Cong. (2005) (permitting churches to engage in campaign intervention "during religious services or gatherings"); American Jobs Creation Act of 2004, H.R. 4520, 108th Cong. $\$ 692$ (as introduced in the House, June 4, 2004) (permitting churches to engage in campaign intervention three times or less, so long as it was not intentional); Houses of Worship Free Speech Restoration Act, H.R. 235, 108th Cong. (2003) (permitting churches to engage in campaign intervention "during religious services or gatherings"); Houses of Worship Political Speech Protection Act, S. 2886, 107th Cong. (2002) (providing a de minimis exception to the Ban for churches and related entities); Bright-Line Act of 2001, H.R. 2931, 107th Cong. (2001) (permitting churches to make annual expenditures for campaign-intervention purposes of up to five percent of gross revenues); Houses of Worship Political Speech Protection Act, H.R. 2357, 107th Cong. (2001) (completely exempting churches from the Ban).

${ }_{12}$ See, e.g., Murphy, supra note 8 , at 80 (arguing that "[n]o cash grant should be given to an organization that engages in political activity, as this is not charitable work"); Tobin, supra note 8, at 1319 ("providing [501(c)(3)] organizations with a subsidy to participate in political campaigns harms both $501(\mathrm{c})(3)$ organizations and our democratic process").

13 See, generally, note 9 , supra.

${ }^{14}$ The focus on funds is also supported by the government's interest in advancing the intentions of donors. Some argue that gifts to charities should not be 
tailor the Ban as closely as possible to the government's interest in expenditure equity, eschewing any attempt to go beyond what is necessitated by the government's interest in expenditure equity. ${ }^{15}$

Developing an "expenditure" paradigm that fully advances the interests of expenditure equity is, however, more complicated than it initially appears. That is because of the difficulty inherent in conceiving valuation methods - really, accounting practices - that would permit an organization, and the Service, to ensure that no taxdeductible funds were used for campaign-intervention activities. This general problem is exacerbated by the fact that one could argue that every time candidate-intervention speech can be attributed to a charity, that charity's credibility is implicated - in which case the expenditures made by the charity to build its credibility were made, to some extent at least, in the service of campaign intervention. Crafting an expenditure paradigm that takes these credibility expenditures into account in a compelling way is daunting indeed. In 2002, a Service representative asked a rhetorical question at a congressional hearing on the Ban: "For example, what is the expenditure related to an endorsement of a candidate during a sermon from the pulpit?"16 Commentators have asked the same question, and, surprisingly, have never attempted to answer it in a systematic or serious way. ${ }^{17}$ If the constitutional analysis in this article is correct, then it is impermissible for Congress to prohibit churches (and other charities) from endorsing a candidate unless that prohibition is related to some expenditure. In Part V, this article argues that an endorsement during a minister's

used by those charities for campaign-intervention activities because donors do not intend for their donations to be used for such purposes. The point is well taken, but like the interest in expenditure equity - can only justify a restriction on the use of funds not an outright ban.

${ }^{15}$ I have avoided calling the solution "narrowly tailored" because of the current debate about what constitutional standard should apply to the issue, discussed infra at note 60 .

${ }^{16}$ Miller, Hearings, supra note 7. To be fair, the Service's attribution-based enforcement strategy, discussed infra at Part IV, could be considered to be an attempt to address the expenditure issues discussed in this article - especially the "credibility" factor. This article argues that the Service's approach of banning all attributable speech is constitutionally problematic, but that the underlying concern with the "value" of the attribution may well be proper, and may well justify an expenditure approach that takes the "cost" of a charity's credibility into account. See infra Part $\mathrm{V}(\mathrm{B})(3)$.

${ }^{17}$ For example, Chris Kemmitt proposes banning only expenditures of taxexempt money for partisan purposes, and he calls enforcement of this proposal "a simple matter." Kemmitt, supra note 9, at 176. 
sermon does entail a cost, and it attempts to explore the complications inherent in measuring that cost. In Part VI, two potential solutions are proposed. ${ }^{18}$

I am agnostic about whether a solution like the ones proposed in this article could simultaneously resolve constitutional concerns and fully advance the interest in expenditure equity. I have not found a theoretical model from which a practical set of valuation rules could be drawn with sufficient specificity to allay all concerns. But I am convinced that adopting an expenditure paradigm - even one that is not entirely satisfactory - would produce multiple benefits, including, most importantly, paying due reverence to the free speech rights that are being trampled by the current interpretation. It is also my suspicion that adopting an expenditure paradigm could potentially decrease campaign intervention by 501(c)(3) organizations. This is so primarily for two reasons. First, I believe that if the Service could shift its enforcement paradigm and focus on the use of tax-deductible funds by 501(c)(3) organizations - if it could corral its enforcement to properly advancing the government's justifiable interest in expenditure equity - then it arguably could enforce the provision more vigorously since its opponents would have had their most powerful defensive argument removed. ${ }^{19}$ Second, if the Service could

${ }^{18}$ This article looks for solutions that could be adopted with little or no change to the statutory framework. It is beyond the scope of this article to discuss the myriad ways that Congress could constitutionally advance expenditure equity goals if it were inclined to change the law.

${ }^{19}$ To date, the Service has not vigorously enforced the Ban. Prior to 2004, the Service had no systematic approach to enforcing the Campaign Intervention Ban. In 2004, 2006 and 2008, the Service conducted Political Activity Compliance Initiatives ("PACI"). As of May 30, 2007, the Service reported that 105 of the 110 cases selected in 2004 have been closed. I.R.S., 2006 Political Activities Compliance Initiative 1, 5 (May 30, 2007). Of those closed cases, $22 \%$ resulted in a finding of "political intervention not substantiated," $6 \%$ resulted in a revocation or proposed revocation, and $66 \%$ resulted in a finding that political activity was substantiated, but the Service took no action other than providing a written advisory. Id. at 5 . Interestingly, when non-church charities are removed from the data, the revocations and proposed revocations drop to zero and the number of cases in which political activity was substantiated but only a written advisory was provided jumps to $92 \%$. Id. In other words, $92 \%$ of churches investigated were found to have engaged in some prohibited campaign intervention, but the IRS chose not to penalize of any of them. As of March 2008 , only 40 of the 100 cases selected for the 2006 PACI have been closed. Id. at 1,5 . But the trend of providing written advisories to organizations that have been determined to have violated the Ban continues ( $65 \%$ of closed cases). $I d$. at 5 . No data is available yet from the $2008 \mathrm{PACI}$. These numbers suggest that the IRS is not yet ready to vigorously enforce the Ban, even if it is making progress in attempting to 
develop a valuation paradigm that identified the hidden costs of campaign-intervention speech - even imperfectly - such activities by 501(c)(3) organizations may be discouraged based on their cost alone. Thus, a shift to an "expenditure" paradigm - far from resulting in increased campaign intervention by charities - may discourage it.

\section{BURDENS AND BENEFITS CONTAINED IN SECTION 501(C)(3) OF THE CODE}

As discussed above, at its core the Ban is an attempt to prevent the benefits of 501(c)(3) status from being used for campaign intervention. ${ }^{20}$ The Ban only applies to 501(c)(3) organizations, not to other 501(c) organizations, although other 501(c) organizations are restricted in the amount of campaign-intervention activities that they may pursue. $^{21}$ Other tax-exempt organizations have campaign

monitor compliance. For a minor update of the results of the 2004 PACI, see Treas. Inspector Gen. for Admin., Improvements Have Been Made to Educate Tax-Exempt Organizations and Enforce the Prohibition Against Political Activities, but Further Improvements are Possible, Ref. No. 2008-10-117 (reporting only 5 outstanding investigations as of January 25, 2008).

${ }^{20}$ Violation of the Ban is punishable by revocation of the organization's taxexempt status under section 501(c)(3). In addition, organizations that lose their exemption because of campaign-intervention activities do not qualify for exemption under 501(c)(4). See I.R.C. $\S 504$. Also, punitive excise taxes may be assessed against organizations and individuals for engaging in campaign-intervention activities. See I.R.C. § 4955; Treas. Reg. \$ 53.4955-1 (1995).

${ }^{21}$ For example, 501(c)(4) organizations may be restricted in the amount of campaign intervention activities they conduct, but they are not banned from conducting any campaign intervention activities. Section 501(c)(4) of the Code states that an organization described therein must be "operated exclusively for the promotion of social welfare." I.R.C. $\S 501(\mathrm{c})(4)$. While the Regulations specify that " $[\mathrm{t}]$ he promotion of social welfare does not include direct or indirect participation or intervention in political campaigns on behalf of or in opposition to any candidate for public office," Treas. Reg. $\S 1.501(\mathrm{c})(4)-1(\mathrm{a})(2)(\mathrm{ii})$ (1990), they also define "exclusively" in the Code to mean "primarily." Treas. Reg. $\$ 1.501(c)(4)-1(a)(2)(i)$ (1990). The Service has expressed the view that campaign intervention activities are permitted so long as they do not overwhelm the primary activity of the organization. See Rev. Rul. 81-95, 1981-1 C.B. 332 (holding that a section 501(c)(4) organization may intervene in campaigns so long as it is "primarily engaged in activities that promote social welfare"); John Francis Reilly \& Barbara A. Braig Allen, Political Campaign and Lobbying Activities of IRS 501(c)(4), (c)(5), and (c)(6) Organizations, in EXempt Organizations Continuing Professional Education TeChNiCal InSTRUCTION PROGRAM FOR FisCal YEAR 2003 L-1, L-2, L-3 (2002). The Service has never specified the amount of campaign intervention activities that would be permitted, or the method for measuring the quantity of such activities. 
intervention as their primary purpose. ${ }^{22}$ Similarly, individuals may of course engage in campaign intervention. Under campaign-finance law, corporations (both business corporations and some nonprofits) are prevented from using the "treasury funds" to engage in certain campaign-intervention activities. ${ }^{23}$ But the reach of this prohibition is significantly more modest than the Ban, and it permits activities by corporations that are prohibited to 501(c)(3) organizations under the Ban. ${ }^{24}$

If the Ban is the burden that distinguishes 501(c)(3) organizations from all other taxpayers, there is only one significant benefit that distinguishes 501(c)(3) organizations from other taxpayers: donations to charities subject to the Ban are generally deductible from the gross income of their donors for income tax purposes. ${ }^{25}$ The deductibility of donations is often called a "subsidy" because it permits a donor to make a donation with "pretax" dollars. ${ }^{26}$ When a donor "deducts" his

${ }^{22}$ Under section 527, "political organizations" are not taxed on contributions, membership dues, or proceeds of a political fundraising event, entertainment event, or bingo game, although the provision imposes a tax on income earned by such organizations through other means (such as investments). See I.R.C. $§ 527(b)(1)$, (c)(3). In addition, section 527 imposes a tax on investment income earned by a 501(c) organization that engages in campaign intervention activities, thus creating an incentive for 501(c)(4) organizations that wish to engage in campaign intervention to do it through a "separate segregated fund." See I.R.C. \& 527(f).

${ }^{23}$ See Federal Election Campaign Act of 1971, as amended (FECA), 2 U.S.C. $\S \S$ 431-57.

${ }^{24}$ See id. The "modest" reach of FECA is due in part to the Supreme Court's defense of corporate speech rights. See, e.g., Buckley v. Valeo, 424 U.S. 1 (1975). The interplay between speech rights in the context of election law and in the context of tax law is beyond the scope of this article.

${ }^{25}$ See I.R.C. $\$ 170(a)(1),(c)(2)$. Contributions to 501(c)(3) organizations are also exempt from gift tax under section 2522 and from estate tax under section 2055(a)(2).

${ }^{26}$ For a discussion of "after tax" status of most campaign intervention expenditures under federal law, see, e.g., Gregg D. Polsky, A Tax Lawyer's Perspective on Section 527 Organizations, 28 CARDOZo L. REV. 1773, 1775-1778 (2007). As discussed above, this difference between "pre-tax" and "post-tax" dollars is normally described as a subsidy from the federal government. But the equity issues are not avoided if one argues that it is inappropriate to regard this distinction as a subsidy. For example, Johnny Rex Buckles argues that the deductibility of contributions to charity "properly" reflects the tax base (and is therefore not a subsidy) because those contributions are "properly attributed not to individual community members, but to the community itself, and the community is not an appropriate object of taxation." Buckles, Peep, supra note 9, at 1082. If passing campaign contributions through a 501 (c)(3) organization enhances their value relative to direct expenditures by individuals because the contribution to the charity can be 
donation, he reduces his or her taxable income by the amount of the donation. ${ }^{27}$ Thus, the amount donated has, at least theoretically, avoided taxation. The fact that dollars contributed to 501(c)(3) organizations are transformed into "pre-tax" dollars has the potential to create substantial incentives to use $501(\mathrm{c})(3)$ organizations as intermediaries in transactions by non-exempt taxpayers. ${ }^{28}$

deducted while a direct contribution to the candidate cannot it is immaterial whether this difference is called a subsidy or not.

${ }^{27}$ Some commentators, however, have pointed out that the tax liability of many donors to 501(c)(3) organizations, especially churches, may not actually be reduced on account of their donations because many taxpayers do not itemize deductions. See, e.g., Douglas H. Cook, The Politically Active Church, 35 LoY. U. CHI. L.J. 457, 471 (2004) (citing Warren Rojas, Finance Looks at Proposals on Charitable Giving, 32 EXEMPT ORG. TAX REV. 245 (2001) for the statistic that seventy percent of taxpayers do not currently itemize). For that reason, some have argued that funds donated to 501(c)(3) organizations, in general, are not subsidized. See, e.g., Samansky, supra note 9, at 151-52 ("the problem of using tax-deductible contributions for political purposes should not be overemphasized. Churches receive much of their contributions from individuals who do not itemize their deductions and thus receive no tax benefit from their charitable donations.") This is an important practical observation, and may be relevant to a church's ability to forego the benefit of deductibility of contributions. See Michael Hatfield, Ignore the Rumors - Campaigning from the Pulpit is Okay: Thinking Past the Symbolism of Section 501(c)(3), 20 NOTRE DAME J.L. ETHICS AND PUB. POL'Y 125, 128 (2006). However, as Hatfield points out, that is an empirical question the answer to which will differ on a case by case basis. See $i d$. While it is true that at least some organizations (and perhaps especially churches) may over-estimate the value of the deductibility of donations, the fact that it appears almost universal that churches choose to be exempt under section 501(c)(3) suggests that they at least perceive some benefit. Even if the deductibility of donations has no value for some organizations, it is legislative concern with the fairness of permitting deductible contributions to $501(\mathrm{c})(3)$ organizations that motivates the expenditure equity concerns underlying the Campaign Intervention Ban. The fact that many taxpayers do not itemize deductions is a flawed basis for an argument about equity issues. See generally Ellen P. Aprill, Churches, Politics and the Charitable Contribution Deduction, 42 B.C. L. REv. 843 (2001) (discussing policy rationales for the charitable contribution deduction). The purpose of the standard deduction is to enable taxpayers with a moderate amount of deductions to avoid the compliance hassles of itemization, and in most cases the standard deduction permits the taxpayer greater tax savings than itemization would permit. See id. at 850 . The legislative history of the standard deduction reveals that its proponents felt they were "tak[ing] account of the average charitable contribution by two and a half percent." Id. at 852 (citing 90 CoNG. REC. 3973 (1944) (statement of Rep. Robertson)). It is inconsistent to argue that the itemized deductions replaced by the standard deduction are thereby erased. They still exist, and the taxpayer still benefits from them (at least in theory); she just saves some record-keeping annoyance.

${ }^{28}$ The Code has various provisions designed to prevent 501(c)(3) organizations from permitting donors receive private benefits in exchange for contributions. For 
As discussed above, it is the deductibility of contributions to 501(c)(3) organizations that creates the government interest in preventing campaign intervention by 501(c)(3) organizations, which I call "expenditure equity." The statutory scheme generally prevents other taxpayers from using "pre-tax" dollars to support candidates, and so it would be inequitable for 501(c)(3) organizations to make campaign contributions with pre-tax dollars. Because deductibility of contributions is the benefit reserved for 501(c)(3) organizations and the Ban is the burden particular to them, the connection between the two is inevitable. ${ }^{29}$

\section{THE CONSTITUTIONAL NECESSITY OF "AFFILIATE ORgANIZATIONS"}

Scholars have argued that the Campaign Intervention Ban is unconstitutional, or at least "constitutionally suspect," for decades.

example, under Treas. Reg. \$1.170A-1(h) (2008), a contribution does not include any amount paid as consideration for a benefit received in return for the contribution. In addition, under I.R.C. $\S 4958$, penalizing excise taxes can be imposed on the parties of an "excess benefit transaction," in which insiders engage in a transaction with a 501(c)(3) organization that provides to them an impermissible private benefit.

${ }^{29}$ For example, Ellen Aprill, in rejecting proffered rationales for the Ban stated simply, "[a] more persuasive justification for the prohibition is that Congress did not wish that tax-deductible contributions to be used for electioneering activities." Aprill, supra note 27 , at 844 .

${ }^{30}$ See, e.g., Wilfred R. Caron \& Deirdre Dessingue, I.R.C. § 501(c)(3): Practical and Constitutional Implications of "Political" Activity Restrictions, 2 J.L. \& POL. 169 (1985) (arguing on free exercise and free speech grounds that the Ban is unconstitutional as applied to churches); Carroll, supra note 4 (arguing on free speech grounds that the Ban is unconstitutional); Chisolm, supra note 9 (arguing on free speech grounds that the Ban is unconstitutional); Edward McGlynn Gaffney, Jr., On Not Rendering To Caesar: The Unconstitutionality of Tax Regulation of Activities of Religious Organizations Relating to Politics, 40 DePaul L. Rev. 1 (1990) (arguing that the Ban violates churches' free speech and free exercise rights); Steffen N. Johnson, Of Politics and Pulpits: A First Amendment Analysis of IRS Restrictions on the Political Activities of Religious Organizations, 42 B.C. L. REv. 875 (2001) (arguing that the Ban violates churches' free speech rights); Kemmitt, supra note 9 (arguing that the Ban violates the Religious Freedom Restoration Act); Klapach, supra note 9, at 511-19 (arguing that while the free exercise and establishment clause arguments are unlikely to be successful, constitutional doubts continue to be raised by free speech, vagueness, and selective prosecution arguments); Randy Lee, The Constitution Under Clinton: A Critical Assessment: When a King Speaks to God: When God Speaks to a King: Faith, Politics, Tax Exempt Status, and the Constitution in the Clinton Administration, 63 LAW \& CONTEMP. PROBS. 391 (2000) (arguing that the Ban as applied violates churches' free exercise rights and violates the Establishment Clause); Meghan J. Ryan, Can the IRS Silence Religious Organizations?, 40 IND. L. 
This article addresses only what I take to be the most compelling argument - that "[a]lthough the decision to withhold the subsidy of exemption and deductibility from the political activity of charitable organizations is probably justified, the further effects of the [Campaign Intervention Ban] provision are not." ${ }^{31}$ In so doing, this article essentially reproduces an argument made by Laura Brown Chisolm eighteen years ago. ${ }^{32}$ The core of the argument is that to the degree that the Ban imposes more than a restriction on using taxdeductible funds for campaign intervention - to the degree it goes beyond advancing a concern with expenditure equity - it violates the Constitution. $^{33}$

Chisolm's argument is premised on the observation that political speech, including speech expressing the speaker's views about candidates and their suitability for office, is protected under the First Amendment $^{34}$ and that the speech of organizations, as well as that of

REV. 73 (2007) (arguing that the Ban is unconstitutional as applied to churches because of a "hybrid" free speech/free exercise claim); Samansky, supra note 9, at 175 (arguing that the Ban is "constitutionally suspect" as applied to churches under the free exercise clause); Smith, supra note 9 (arguing that the Ban as applied to churches violates the free speech, free exercise, and possibly establishment clauses); Zimmerman, supra note 9, at 266 (arguing that the Ban constitutes an "impermissible hindrance" to free exercise and free speech rights).

${ }^{31}$ Chisolm, supra note 9, at 327.

${ }^{32}$ Chisolm, supra note 9, at 319-53.

${ }^{33}$ Following Chisolm, I focus the constitutional analysis on free speech principles. Many commentators instead have argued that the Ban is unconstitutional because it violates the Free Exercise Clause, emphasizing the differences between churches and other 501(c)(3) organizations. This article does not address these arguments. Because a church's right to political speech, including the express endorsement of candidates, is protected under the Constitution, it is not clear what is added when one asserts (however truthfully) that a church's religious mission may require it to engage in such speech. That being said, it is worth acknowledging that the fundamental premise of many of these articles - that the Campaign Intervention Ban may apply to religiously mandated speech, and therefore may force churches to make a choice between 501(c)(3) status and fulfilling their religious mission - should not be taken lightly. As commentators have pointed out, there may be some whose religious commitments are such that the Ban impedes their ability to meet their religious obligations. See, e.g., Lee, supra note 30, at 401.

${ }^{34}$ Chisolm supra note 9, at 319, n.59 (citing Monitor Patriot Co. v. Roy, 401 U.S. 265, 272 (1971) (noting that discussions of candidates is speech to which the First Amendment "has its fullest and most urgent application"); Buckley v. Valeo, 424 U.S. 1,14 (1976) (stating that "debate on the qualifications of candidates" is among "the most fundamental First Amendment activities"); Mills v. Alabama, 384 U.S. 214, 218 (1966) ("Whatever differences may exist about interpretations of the First Amendment, there is practically universal agreement that a major purpose of that 
natural persons, is protected. ${ }^{35}$ Having established that campaignintervention speech by organizations is generally protected under the First Amendment, Chisolm argues that the so-called "unconstitutional conditions" doctrine applies to the Campaign Intervention Ban because the Ban requires "an organization to choose between exercising its right to political expression and receiving a benefit to which it is otherwise entitled." ${ }^{36}$

The leading case is Regan v. Taxation With Representation of Washington (TWR) ${ }^{37}$ In that case, the Supreme Court held that the lobbying restrictions contained in section 501(c)(3) of the Code did not infringe the First Amendment free-speech rights of an organization that was exempt under section 501(c)(3). ${ }^{38}$ The analysis in that case depended on distinguishing Speiser $v$. Randall, which held that the U.S. Constitution prohibited the California constitution from requiring that veterans sign a loyalty oath to receive benefits, ${ }^{39}$ from Cammarano v. U.S., which held that the Constitution did not prohibit Congress from refusing to permit a business deduction for business corporations engaged in lobbying. ${ }^{40}$ The distinction between these cases made by the Court, as Chisolm points out, is that the nondeductibility provision in Cammarano "simply [requires taxpayers] to pay for those [constitutionally protected] activities entirely out of their own pockets" while "the provision challenged in

Amendment was to protect the free discussion of governmental affairs. This of course includes discussions of candidates....")). Just last term, the Court reiterated this position in FEC v. Wis. Right to Life, Inc., 127 S. Ct. 2652, 2663-64 (2007) (holding that discussion of candidates' qualifications, including expressly advocating their election or defeat, is "political speech" and is therefore "subject to strict scrutiny").

${ }^{35}$ Chisolm supra note 9, at 320, n.63 (citing Consolidated Edison Co. v. Public Serv. Comm'n, 447 U.S. 530, 533 (1980); First Nat'l Bank of Boston v. Belotti, 435 U.S. 765,777 (1978)). See, also FEC v. Mass. Citizens for Life, Inc., 479 U.S. 238 (1986).

${ }^{36}$ Chisolm, supra note 9, at 319-20. The unconstitutional conditions doctrine has been called "the basic structural issue that for over a hundred years has bedeviled courts and commentators alike." Richard A. Epstein, Unconstitutional Conditions, State Power, and the Limits of Consent, 102 HARV. L. REV. 4, 6 (1988), quoted in Rust v. Sullivan, 500 U.S. 173, 205 (1991) (Blackmun, J., dissenting).

${ }^{37}$ Regan v. Taxation With Representation of Washington (TWR), 461 U.S. 540 (1983).

${ }^{38}$ Id. at 546. As discussed supra note 2, section 501(c)(3) prohibits campaign intervention activities and separately restricts the total amount of lobbying activities that may be conducted by a charity.

${ }^{39}$ Speiser v. Randall, 357 U.S. 513 (1958).

so Cammarano v. U.S., 358 U.S. 498 (1959); see also 461 U.S. at 545-51 for the Court's discussion of Speiser and Cammarano. 
Speiser did not merely decline to help pay for particular speech, but rather extracted an independent penalty (in the form of a withheld benefit) unless the taxpayer agreed to forgo the exercise of his guaranteed right of free expression. ${ }^{41}$ Under this analysis, it first appears that the ban on lobbying found in Section 501(c)(3) should be unconstitutional, because by denying tax-exempt status to anyone who engages in substantial lobbying, it goes beyond prohibiting the use of deductible contributions for lobbying.

But the Court found that it was not unconstitutional, explaining that the organization is not faced with an unconstitutional condition because the Code permits the 501(c)(3) organization to conduct unlimited lobbying activities, so long as it uses a non-501(c)(3) affiliate to fund them. ${ }^{42}$ The Court noted that TWR was created to carry on the activities of two separate organizations: one exempt under 501(c)(3) and one exempt under 501(c)(4). ${ }^{43}$ Prior to the formation of TWR, these two organizations divided up the activities that were later assumed by TWR, with the 501(c)(3) conducting activities that were intended to avoid the political activity restrictions in the Code and the 501(c)(4) conducting those activities that are the subject of these restrictions. ${ }^{44}$ The Court noted that despite the fact that TWR's exemption could be denied because of substantial lobbying, such denial is not a penalty because,

TWR can obtain tax-deductible contributions for its nonlobbying activity by returning to the dual structure it used in the past, with a $\$ 501(\mathrm{c})(3)$ organization for non-lobbying activities and a $\$ 501(\mathrm{c})(4)$ organization for lobbying. TWR would, of course, have to ensure that $\$ 501(\mathrm{c})(3)$ organization did not subsidize the $\$ 501(c)(4)$ organization; otherwise

${ }^{41}$ Chisolm supra note 9, at 323 (quoting Cammarano, 358 U.S. at 513). Justice Douglas illustrated this distinction very clearly in his concurrence in Cammarano. He wrote: "[I]f Congress had gone so far as to deny all deductions for 'ordinary and necessary business expenses' if a taxpayer spent money to promote or oppose initiative measures, then it would be placing a penalty on the exercise of First Amendment rights." 358 U.S. at 515 (Douglas, J., concurring).

${ }^{42}$ See Chisolm, supra note 9, at 325 (citing TWR, 461 U.S. at 545) (noting that "the Internal Revenue Code allows the organization to segregate the nonsubsidized activity fiscally and structurally and thereby avoid the independent penalty effect of the provision").

\footnotetext{
${ }^{43} T W R, 461$ U.S. at 543.

${ }^{4}$ Id.
} 
public funds might be spent on activity Congress chose not to subsidize. ${ }^{45}$

The Court differentiated between an over-all statutory structure that prevented certain activities from being subsidized from one that prevented an organization that engages in certain activities from receiving government benefits for anything, stating, "Congress has merely refused to pay for the lobbying out of public moneys." avenue for TWR to conduct substantial lobbying activities is provided in the Code: it must simply create a 501(c)(4) affiliate to carry on those activities with non-subsidized donations.

In this article, I call the mechanism described by the Court which saves section 501(c)(3) from imposing an unconstitutional condition on charitable entities wishing to engage in substantial lobbying - the "affiliate organization solution." only thing that saves the lobbying provision in section 501(c)(3) from being an unconstitutional condition is the fact that a 501(c)(3) organization can use an affiliate organization to do its lobbying for it, the Campaign Intervention Ban is also an unconstitutional condition unless a similar solution exists to enable 501(c)(3) organizations to conduct campaign intervention activities through an affiliate organization $^{48}-$ or so the argument goes. ${ }^{49}$

${ }^{45}$ Id. at 544 .

${ }^{46} I d$. at 545.

${ }^{47}$ See Miriam Galston, Campaign Speech and Contextual Analysis, 6 FIRST AMEND. L. REV. 100 (2007) (calling the affiliate organization solution the "alternate channel doctrine").

${ }^{48}$ The TWR Court made clear that the Service's interpretation of the interaction between sections 501(c)(3) and 501(c)(4) of the Code is essential to those provisions' constitutionality. The Court described a concern by some amici that the Service would "impose stringent requirements that are unrelated to the congressional purpose of ensuring that no tax-deductible contributions are used to pay for substantial lobbying, and effectively make it impossible for a 501(c)(3) organization to establish a 501(c)(4) lobbying affiliate." TWR, 461 U.S. at 544 n.6. The Court noted that "[n]o such requirement in the Code or regulations has been called to our attention, nor have we been able to discover one. The IRS apparently requires only that the two groups be separately incorporated and keep records adequate to show that tax-deductible contributions are not used to pay for lobbying." Id. Thus, the Court's reasoning suggests that a Service regulatory paradigm that unduly burdened the ability of a 501(c)(3) organization to use a 501(c)(4) affiliate to conduct its lobbying could render the statutory scheme unconstitutional. See id. Justice Blackmun made this point even more explicitly in his concurrence, stating, "[a]s long as the IRS goes no further than this, we perhaps can safely say that '[the] Code does not deny TWR... any independent benefit on account of its intention to lobby.'... A \$501(c)(3) 
The concurrence by Justice Blackmun (joined by Justices Brennan and Marshall) was even more explicit about the dependence of the constitutionality of the political activity restrictions in section 501(c)(3) on the affiliate organization solution. ${ }^{50}$ Justice Blackmun wrote that,

[b]ecause lobbying is protected by the First Amendment ... $\$ 501(c)(3)$ therefore denies a significant benefit to organizations choosing to exercise their constitutional rights. The constitutional defect that would inhere in $\$ 501(\mathrm{c})(3)$ alone is avoided by $\$ 501(\mathrm{c})(4)$. As the Court notes ... TWR may use its present $\$ 501(c)(3)$ organization for its nonlobbying activities and may create a $\$ 501(\mathrm{c})(4)$ affiliate to pursue its charitable goals through lobbying. ${ }^{51}$

organization's right to speak is not infringed, because it is free to make known its views on legislation through its 501(c)(4) affiliate without losing tax benefits for its nonlobbying activities." Id. at 553 (Blackmun, J., concurring) (citation omitted).

${ }^{49}$ As Chisolm argued, the Ban is unconstitutional because "[n]o effective alternative avenues for nonsubsidized expression of campaign-related political opinion are available to a section 501(c)(3) organization." Chisolm, supra note 9, at 328.

${ }^{50}$ As several commentators have pointed out, the Court's opinion relies on the logic of Justice Blackmun's concurrence. If there was any doubt that Justice Blackmun's concurrence correctly states the law, it was resolved in FCC v. League of Women Voters, 468 U.S. 364, 400 (1984), in which the Court adopted Justice Blackmun's reasoning.

${ }^{51} T W R, 461$ U.S. at 552 (Blackmun, J., concurring) (citations omitted). Justice Blackmun also makes explicit in his concurrence that the $501(\mathrm{c})(3)$ organization itself has constitutionally protected speech rights. Because of that, the 501(c)(3) organization must be afforded some opportunity to communicate its views in such a way that they may be attributed to $i t$, and not to some affiliate. Justice Blackmun wrote:

It must be remembered that $\$ 501(\mathrm{c})(3)$ organizations retain their constitutional right to speak and to petition the Government. Should the IRS attempt to limit the control these organizations exercise over the lobbying of their $\$ 501(c)(4)$ affiliates, the First Amendment problems would be insurmountable. It hardly answers one person's objection to a restriction on his speech that another person, outside his control, may speak for him. Similarly, an attempt to prevent $\$ 501(c)(4)$ organizations from lobbying explicitly on behalf of their $\$ 501(c)(3)$ affiliates would perpetuate $\$ 501$ (c)(3) organizations' inability to make known their views on legislation without incurring the unconstitutional penalty. Such restrictions would extend far beyond Congress' mere refusal to subsidize 
In the same term as $T W R$, the Court decided FCC $v$. League of Women Voters, striking down a law denying funding to radio stations that "engage in editorializing." 52 In that case, the Court recognized that if Congress had structured the law so that recipient stations could "establish 'affiliate' organizations which could then use the station's facilities to editorialize with nonfederal funds, such statutory mechanism would plainly be valid." ${ }^{53}$ As it had in TWR, the Court reasoned that constitutionally-protected speech was not being burdened as long as the speaker was free to engage in protected speech. The government was free to prohibit the use of government funds or subsidies for such speech even if such prohibition forced the speaker to use a separate legal entity to communicate its message. However, a statutory scheme that makes it impossible for an entity to engage in protected speech without forfeiting a subsidy for more than just that speech would be prohibited.

The Court relied on the existence of a sort of "affiliate organization solution" in Rust v. Sullivan as well. ${ }^{54}$ There the Court facially upheld an administrative interpretation of federal law that conditioned provision of funds for family planning on governmentfunded projects refraining from providing information about abortion to patients. Central to the Court's holding was the fact that the "regulations do not force the Title $\mathrm{X}$ grantee to give up abortionrelated speech; they merely require that the grantee keep such activities separate and distinct from Title $X$ activities." ${ }^{55}$ The Court emphasized the distinction between a restriction on the project (which can give no abortion-related information) and the grantee (who is free to do so outside the context of the program). The Court then analogized to the affiliate organization solution discussed in TWR and League of Women Voters.

While the Supreme Court has only addressed the lobbying restriction and not the Campaign Intervention Ban, the D.C. Circuit has analyzed the Campaign Intervention Ban. ${ }^{56}$ Here, the court treated the First Amendment claim by a church under a free exercise,

lobbying.... In my view, any such restriction would render the statutory scheme unconstitutional.

Id. at 553-54 (Blackmun, J., concurring) (emphasis added) (citation omitted).

${ }^{52}$ FCC v. League of Women Voters, 468 U.S. 364, 366, 402 (1984).

${ }^{53} I d$. at 400.

${ }^{54}$ Rust v. Sullivan, 500 U.S. 173 (1991).

${ }^{55}$ Id. at 196.

56 Branch Ministries v. Rossotti, 211 F.3d 137 (D.C. Cir. 2000). 
rather than a free speech, analysis. ${ }^{57}$ The court makes it clear, however, that the affiliate organization solution, described in $T W R$, is essential to its holding that the Ban does not violate the church's constitutional rights. It found that

three members of the Supreme Court stated that the availability of such an alternative means of communication is essential to the constitutionality of section 501(c)(3)'s restrictions on lobbying. The Court subsequently confirmed that this was an accurate description of its holding. See FCC v. League of Women Voters, 468 U.S. 364, 400 (1984). . . .

The Church has such an avenue available to it. As was the case in TWR, the Church may form a related organization under 501(c)(4) of the Code.... Such organizations are exempt from taxation; but unlike their section 501(c)(3) counterparts, contributions to them are not deductible. ${ }^{58}$

Thus, the court's holding was dependent on the availability of an affiliate organization solution, like those identified in TWR, League of Women Voters, and Rust v. Sullivan.

Other recent cases in the Second Circuit Court of Appeals have reaffirmed the basic principle that when the government provides funds to an organization on condition that the organization not use those funds to engage in certain activities, it must ensure that there is an adequate alternate channel available for the organizations to engage in constitutionally protected activities using private funds. ${ }^{59}$ While these cases raise the question of what standard a court should apply in determining whether the "alternate channel" provided under the law is sufficient to avoid constitutional concerns, they appear to agree that an "adequate" alternative channel is one that does not

57 It found that the free exercise rights of the church were not substantially burdened (the first prong of the test) because its withdrawal from electoral politics will not "violate its beliefs," and because a decrease in the amount of money available for its religious practices "is not constitutionally significant." Id. at 142 (citation omitted). The court also separately held that the church's free speech rights were not violated because of viewpoint discrimination because "[t]he restrictions imposed by section 501(c)(3) are viewpoint neutral." Id. at 144.

${ }^{58} I d$. at 143.

${ }^{59}$ See, e.g., Velazquez v. Legal Services Corp. (Velazquez IV), 349 F. Supp. $2 \mathrm{~d}$ 566, 600 (E.D.N.Y. 2004); Brooklyn Legal Services Corp. v. Legal Services Corp. (Velazquez V), 462 F.3d 219, 232 (2d Cir. 2006); Alliance for Open Society Int'l, Inc. v. U.S. Agency for Int'l Dev., 430 F. Supp. 2d 222, 259 (S.D.N.Y. 2006). 
"unduly burden" the speech of recipients of government largesse." That is, the statutory scheme only imposes burdens (1) that are reasonably related to the government's legitimate interests and (2) that are not overall so costly as to prevent constitutionally protected speech. ${ }^{61}$

The second prong of the "undue burden" test presumably involves a case-by-case analysis of the overall cost for specific organizations to engage in protected campaign-intervention speech in compliance with the Campaign Intervention Ban. ${ }^{62}$ But the first prong demands that the Ban be crafted only to advance the government's interest and not go beyond. Therefore, if government interests only justify banning the expenditure of tax-deductible funds on campaign

${ }^{60}$ In TWR and Rust $v$. Sullivan, the court held that the legislation at issue was authorized under Congress's very broad spending power, which is conferred under Art. I, $\S 8$, cl. 1.1 of the Constitution. If only Congress's spending power is at issue, legislation would presumably only violate the Constitution if there were no rational basis for it, which is a very low bar. Since TWR, League of Women Voters and Rust v. Sullivan relied on the existence (or lack) of an adequate alternative channel, and that alternative channel imposed some burden on an organization's speech, the natural question is: what standard should a court employ to evaluate the adequacy of the alternative channel? Must its burdens be justified as "narrowly tailored" to advance the government's interest or can they be only "rationally related" to such interests? At least one commentator has described the Court's treatment of the proper standard of review in alternative channel cases as "murky, circular, and subject to at least two possible interpretations." Edward Chaney, Velazquez v. Legal Services Corporation: Unconstitutional Conditions and First Amendment Rights of Nonprofit Organizations and Their Donors, 4 First AMEND. L. REv. 267, 280 (2006). In Velazquez IV, 349 F. Supp. 2d at 600, the United States District Court for the Eastern District of New York concluded that the proper test of whether a regulation of content-neutral speech imposes an "undue burden" is "an intermediate form of review" that is neither rational review nor strict scrutiny, but which instead requires a balancing of the government's interests against the speaker's rights. The Second Circuit Court of Appeals subsequently reversed Velazquez $I V$, holding that the alternative channel must be "adequate" but that no heightened standard of review was appropriate to determine its adequacy. See Velazquez V, 462 F.3d at 232

${ }^{61}$ See Velazquez $V, 462$ F.3d at 232 (holding that "[b]y definition, an alternative is inadequate if the government substantially or unduly burdens the ability to create the alternative" and that "separation requirements" may be unconstitutional if "they imposed extraordinary burdens that impede grantees from exercising their First Amendment rights, created prohibitive costs of compliance, and demanded an unjustifiable degree of separation of affiliates").

${ }^{62}$ Michael Hatfield has done the most to evaluate what the burden of foregoing 501(c)(3) status would be for a church. See Hatfield, supra note 27, at 148-69. His main point is that churches may overestimate the burden, but he concedes that the cost for each church must be determined on a case-by-case basis, and may be significant in certain instances. 
intervention, a Ban that absolutely prohibited campaign-intervention speech by 501(c)(3) organizations - irrespective of the use of funds would be impermissible. Forcing an organization to forgo or give up 501(c)(3) status in order to engage in campaign-intervention speech is an "undue burden" because it is not justified by the government's interest in expenditure equity. If an activity is truly free - or is fully reimbursed by a non-501(c)(3) organization - then the argument is that the Constitution requires that $501(\mathrm{c})(3)$ organizations be permitted to engage in it. ${ }^{63}$

Of course, one could argue that the Service's method is justified by some government interest other than expenditure equity, if an interest could be found that could justify the burden imposed under the Service's current enforcement paradigm. So, it is worth asking whether there is another governmental interest - other than expenditure equity - that is reasonably related to the Service's interpretation of the Ban. Because of an absence of legislative history, scholars have had to speculate about potential government interests. ${ }^{64}$ Some have attempted to review other potential governmental interests - such as protection of churches' independence, ${ }^{65}$ avoidance

${ }^{63}$ In Rust $v$. Sullivan, the Court held that the government was justified in requiring that an organization carry on its subsidized activities and its unsubsidized activities in separate places and with separate employees. Rust v. Sullivan, 500 U.S. 173, 191 (1991). However, these so-called "program integrity" requirements were explicitly justified by the government on the grounds that without them "the public can get the impression that Federal funds are being improperly used for [unsubsidized] activities." Id. at 188. That justification simply doesn't apply to the charitable context. If the government is justified in being concerned that the public could get the impression that a charity is using the subsidies provided under the Code to say something like, "elect Candidate X," mustn't it be equally concerned that the charity is using the funds to say "Jesus is the one true way" or "There is no God but Allah"? In other words, the fact that the subsidy is constitutionally available for religious speech suggests that there is no danger that the public will understand the subsidy to imply a governmental endorsement of a charity's speech.

${ }_{64}^{64}$ See, e.g., Lloyd Hitoshi Mayer, Grasping Smoke: Enforcing the Ban on Political Activity By Charities, 6 FIRST AMEND. L. REv. 1, 2 (2007) [hereinafter, Mayer, Grasping Smoke] ("[d]espite valiant attempts by many scholars, the exact reasons behind Congress' enactment of the prohibition remain obscure").

${ }^{65}$ Some commentators have argued that engaging in campaign intervention is bad for churches for any number of reasons, and that protecting churches from themselves or from vulnerability to political actors who would make use of them may be an important government interest. See, e.g., Tobin, supra note 8, at 1322-25 (arguing that intervention harms churches because they may be co-opted by government, candidates may be tempted to intimidate churches, campaign intervention may result in politically "preferred" churches, and political intervention may cause discord within churches). While some of these concerns may constitute 
of private benefit, and definitional consistency in the concept of charity $^{66}$ - but none have found a compelling one. ${ }^{67}$ In the campaign context, it is obvious to think first of the governmental interests generally justifying regulation of campaign finance. ${ }^{68}$ However,

legitimate government interests, it must be remembered that the fact that a specific course of action may be best for the private actor involved does not necessarily justify employing the coercive power of the State in favor of that action. During the question-and-answer period following the presentation of this paper at the Loyola Law School of Los Angeles Tax Policy Colloquium, one student commented, "I don't want to go to a church that endorses candidates," and suggested that regulation of church speech by the government advances the interests of church-goers who want their churches to remain apolitical. See, also De Leon, supra note 8, at 710 (citing evidence that "church members generally reject being told how to vote by their churches"). But see James, supra note 9, at 371 (noting that the African-American church was established not only to "preach the Gospel", but also to "improve socioeconomic conditions for the nation's African-Americans"). But to the degree that commentators are concerned about religious organizations being corrupted by the political process, the Constitution limits the power of the federal government to control the behavior of churches, even in the church's best interests. First Amendment values require that citizens eschew using the government to control the speech of churches, even their own churches. That is to say, "[t]he antidote which the Constitution provides against zealots who would inject sectarianism into the political process is to subject their ideas to refutation in the marketplace of ideas and their platforms to rejection at the polls." McDaniel v. Paty, 435 U.S. 618, 642 (1978) (Brennan, J., concurring). Likewise, arguments that the Ban is justified by the government interest in avoidance of entanglement between church and state are not persuasive. For a discussion of why such arguments are not persuasive, see Johnny Rex Buckles, Does the Constitutional Norm of Separation of Church and State Justify the Denial of Tax Exemption to Churches that Engage in Partisan Political Speech?, 84 IND. L.J. 447 (2009).

${ }^{66}$ See, e.g., Chisolm, supra note 9, at 333-52. Chisolm lists the following potential government interests served by the Ban: (1) nonsubvention (i.e. expenditure equity); (2) avoiding advancing "private interests;" and (3) a definitional inconsistency between charitable and campaign-intervention activities. Id. at 352-61, After discussing these putative interests at length, Chisolm concludes that while these are legitimate governmental interests, none of them justifies a ban on campaign intervention that goes beyond restricting the use of governmentally-subsidized funds. Id. at 361 .

${ }^{67}$ See, e.g., Carroll, supra note 4, at 250-56 ("[T]he government has shown no compelling, or even substantial, interest that would justify [a Ban that goes beyond restricting expenditures]").

68 The Supreme Court has repeatedly held that a there is a compelling government interest in "deterring actual corruption and avoiding any appearance thereof." McConnell v. Federal Election Commission, 540 U.S. 93, 196 (2003). This interest, combined with the recognition of "the corrosive and distorting effects of immense aggregations of wealth that are accumulated with the help of the corporate form," justifies regulation. Id. at 205 (quoting Austin v. Michigan State Chamber of 
ultimately, until the government is forced to formulate the governmental interest - other than expenditure equity - that justifies the application of the Ban to more than just restricting expenditures, it is reasonable to conclude that "there is no defensible basis for singling out Section 501(c)(3) organizations, alone among tax-exempt groups, for loss or denial of exempt status solely on the grounds of political speech or activity." ${ }^{169}$

\section{Two DisTinct MODES OF ANALYSIS: ATTRIBUTION AND EXPENDITURE}

If the Constitution requires that the Campaign Intervention Ban go no farther than prohibiting the use of tax-deductible funds for campaign-intervention purposes, then the Service's current interpretation of the Ban is likely unconstitutional. The Service currently interprets the Ban to absolutely prohibit campaignintervention activities that can be attributed to a 501(c)(3) organization, no matter who pays for those activities. Thus, if a charity wishes to endorse a candidate (officially or unofficially), its only legal means to do so is to give up its 501(c)(3) status.

In May of 2000, the U.S. Court of Appeals for the District of Columbia Circuit decided what is apparently the only case - Branch Ministries $v$. Rossotti - in which the Service revoked the tax-exempt status of a church for engaging in campaign intervention. ${ }^{70}$ That case

Commerce, 494 U.S. 652,660 (1990)). The Court has therefore upheld limitations on expenditures of treasury funds by corporations and labor unions. These restrictions have also passed constitutional muster when applied to certain non-profit organizations that are not formed expressly for political purposes. See id. at 211; Austin, 494 U.S. at 655 . However, these restrictions only apply to the expenditure of treasury funds, and the constitutionality of such restrictions is expressly dependent on the ability of these organizations to use affiliates or segregated funds to engage in campaign intervention. I know of no case that suggests that the governmental interest in deterring corruption and avoiding the appearance thereof justifies not only a ban on the use of an entity's funds to engage in campaign intervention, but also a ban on the entity engaging in such speech using funds raised specifically for that purpose on a non-tax-deductible basis. In fact, in FEC v. Massachusetts Citizens for Life, the Court apparently held the opposite, when it found that forcing nonprofit corporations to abide by the record-keeping and disclosure requirements of the Federal Election Campaign Act was a substantial burden - even though such organizations receive a "subsidy" from the federal government - stating "[t]he fact that the statute's practical effect may be to discourage protected speech is sufficient to characterize $\$ 441 \mathrm{~b}$ as an infringement on First Amendment activities." 479 U.S. 238, 255 (1986).

69 Carroll, supra note 4, at 219.

${ }^{70}$ Branch Ministries v. Rossotti, 211 F.3d 137 (D.C. Cir. 2000). The District 
involved what was widely heralded as especially egregious behavior by the church, called The Church at Pierce Creek, which had taken out a full-page advertisement in two newspapers that "urged Christians not to vote for then-presidential candidate Bill Clinton because of his positions on certain moral issues." notation at the bottom of the page that identified its "co-sponsors" and stated, " $[\mathrm{t}] \mathrm{ax}$-deductible donations for this advertisement gladly accepted. Make donations to: The Church at Pierce Creek." ${ }^{, 2}$ The court agreed with the Service that the advertisements constituted campaign intervention prohibited under section 501(c)(3), and rejected the church's arguments that the Service was without statutory or constitutional authority to revoke its exemption. ${ }^{73}$

While some commentators have argued that some campaignintervention activities should be beyond the reach of the Ban, ${ }^{74}$ few commentators have failed to recognize that the advertisements taken out by the Church at Pierce Creek represented an egregious breach of the $\mathrm{Ban}^{75}$ a view the court hearing the case expressed as well. ${ }^{76}$ However, there has been very little direct analysis of what about this particular ad makes it such a clear violation, and why this violation so clearly warrants enforcement of the Ban. The reason this analysis is

Court apparently accepted the Church's factual claim that the IRS had never revoked the tax exempt status of a bona fide church before, although it noted that it had revoked the tax-exempt status of religious organizations because of political activities twice before. See Branch Ministries v. Rossotti, 40 F. Supp. 2d 15, 22 (D.D.C. 1999) (citing Christian Echoes National Ministry, Inc. v. U.S., 470 F.2d 849 (10th Cir. 1973) and discussing a case involving The Way International).

" 211 F.3d at 139. The advertisement is reproduced as an appendix in Lee, supra note 30 , at 437 .

${ }^{72} 211$ F.3d at 140.

${ }^{73}$ The court also rejected arguments by the church that selective prosecution by the IRS invalidated the IRS's revocation of exempt status under the Fifth Amendment. Id. at 144-45.

${ }^{74}$ See generally articles cited supra note 9.

75 See Hatfield, supra note 27, at 138 (stating that as "best I can tell, no legal scholar has claimed the appeals court got it wrong."). But see Zimmerman, supra note 9, at 263 (arguing that the court "missed the point" with regard to the church's free speech claim); Kemmitt, supra note 9, at 170 ("[W]hile the D.C. Circuit cited the proper legal standard, it failed to apply it correctly to the facts at hand.").

${ }^{76}$ In discussing the Church's selective prosecution claim, the District Court stated that the Church had not identified any "other instance in which a church so brazenly claimed responsibility for a political advertisement" and that it "provided no evidence of an instance in which a political act could so easily be attributed to a taxexempt church." 40 F. Supp. 2d at 21 (emphasis added). 
necessary is that there are actually two distinct modes of analysis to determine why the ad was a breach of the Ban.

In the Service's view, the communication to voters of a view about a candidate for public office is sufficient to constitute a violation of the Ban so long as the author of the communication - the speaker, so to speak - is a 501(c)(3) organization. While commentators have complained about a lack of clarity in guidance issued by the Service regarding campaign intervention, ${ }^{77}$ the Service released guidance last year - in the form of a revenue ruling - explaining its view on campaign intervention by 501(c)(3) organizations ${ }^{78}$ from which one message at least is clear: the Service's central concern is attribution of a favorable or negative view of a candidate. ${ }^{79}$ That is, the Service

77 For example, the only relevant regulation is Treas. Reg. 1.501(c)(3)1(c)(3)(iii) (2008), which states in its entirety: "An organization is an 'action' organization if it participates or intervenes, directly or indirectly, in any political campaign on behalf of or in opposition to any candidate for public office. The term 'candidate for public office' means an individual who offers himself, or is proposed by others, as a contestant for an elective public office, whether such office be national, state, or local. Activities which constitute participation or intervention in a political campaign on behalf of or in opposition to a candidate include, but are not limited to, the publication or distribution of written or printed statements or the making of oral statements on behalf of or in opposition to such a candidate." Other guidance and enforcement action by the IRS has arguably changed in approach over time, has been haphazard, or has failed to clearly describe the principles being applied. See, e.g., Rev. Rul. 86-95, 1986-2 C.B. 73; Rev. Rul. 80-282, 1980-2 C.B. 178; Rev. Rul. 78-248, 1978-1 C.B. 154; I.R.S. Gen. Couns. Mem. 39,694 (Feb. 2, 1988); I.R.S. Gen. Couns. Mem. 38,444 (July 15, 1980); I.R.S. Gen. Couns. Mem. 38,137 (Oct. 22, 1979); I.R.S. Gen. Couns. Mem. 35,902 (July 15, 1974); I.R.S. Tech. Adv. Mem. 200446033 (June 15, 2004); I.R.S. Tech. Adv. Mem. 200437040 (June 7, 2004); I.R.S. Tech. Adv. Mem. 9635003 (Apr. 19, 1996); I.R.S. Tech. Adv. Mem. 9609007 (Dec. 6, 1995); I.R.S. Tech. Adv. Mem. 9117001 (Sept. 5, 1990); I.R.S. Priv. Ltr. Rul. 200602042 (Jan. 13, 2006); I.R.S. Priv. Ltr. Rul. 9152039 (Sept. 30, 1991); I.R.S. Notice 94-111, 1994 I.R.B. 36; I.R.S. Notice 88-76, 1988-2 C.B. 392; I.R.S. News Release I.R. 9623 (Apr. 24 1996); I.R.S. Fact Sheet FS 2006-17 (Feb. 2006); Reilly \& Allen, supra note 21; Ward L. Thomas \& Judith E. Kindell, Affiliations Among Political, Lobbying and Educational Organizations, in IRS EXEMPT ORganizations CONTINUING PROFEsSIONAL

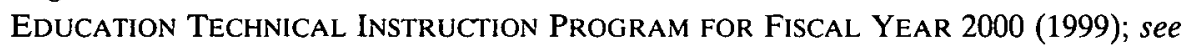
also, Unpublished Tech. Adv. Mem. Tax Analysts Doc. No. 1999-5081 (regarding the Progress and Freedom Foundation).

${ }^{78}$ Rev. Rul. 2007-41, 2007-25 I.R.B. 1421 (June 18, 2007). The IRS's willingness to commit itself to an enforcement paradigm by issuing a revenue ruling is notable. While revenue rulings are not entitled to judicial deference in the way that regulations would be, they are an official communication from the IRS stating its interpretation of the application of the law to certain facts, and therefore can be taken as indicative of its enforcement paradigm.

79 I call a view about the suitability of a candidate (positive or negative) that can 
interprets the Ban to prohibit activities that - under all the facts and circumstances - communicate that the 501(c)(3) organization itself supports one candidate over another. ${ }^{80}$

Under the Service's analysis, the court would have no problem determining that the Church at Pierce Creek's advertisement violated the Ban. The advertisement (1) identified a 501(c)(3) organization as one of its "co-sponsors"; (2) was placed in major newspapers four days before an election; (3) identified a candidate by name; (4) described his policies as "in rebellion to God's laws;" and (5) concluded with the call to action, "How then can we vote for Bill Clinton?" clear (1) that the church itself (and not the minister or some affiliated non-church organization acting on its own account) is the speaker; (2) that the communication concerns a specific candidate for an election (and not an issue); (3) that the advertisement communicates a clear preference between the candidates (and is not neutrally presenting information about the candidates); and (4) that the advertisement communicates a view regarding how the reader should behave with regard to the candidate (vote against him). What is egregious about the advertisement under this "attribution" analysis is that the church identifies itself as the speaker and it explicitly expresses an unambiguous view about a candidate.

But what if the church attempted to use a non-501(c)(3) affiliate organization to communicate its message, as is discussed in TWR and Branch Ministries? Imagine that the advertisement had been paid for by a 501(c)(4) or 527 affiliate of the Church and the request for donations had stated "non-deductible donations for this

be attributed to an organization an "endorsement" herein, even though I am aware that some commentators have attempted to reserve the word "endorsement" for some "official" communication of an organization's choice of candidate in an election. See, e.g., Samansky, supra note 9, at 178-79.

${ }^{80}$ The Revenue Ruling contains twenty-one examples that are designed to illustrate seven categories of questionable activities. With the exception of categories five and four, which attempt to define the limits of what constitutes campaign intervention itself, the categories all address the question of whether activities should be attributed to the organization. The underlying principle is that if a preference among candidates can be attributed to the organization, then the organization has committed a prohibited campaign-intervention activity. The organization can only avoid such prohibited activities by making sure that no view on the qualifications of candidates can be attributed to it, generally by acting neutrally with regard to the candidates.

${ }^{81}$ Branch Ministries v. Rossotti, 40 F. Supp. 2d 15, 17 (D.D.C. 1999). 
advertisement gladly accepted." ${ }^{82}$ Under that scenario, a reader who is familiar with the law of tax-exempt organizations - or one who has read $T W R$ - would assume that the communication would be permitted. Of course a non-501(c)(3) organization may take out an advertisement urging voters to vote for or against a candidate for public office. ${ }^{83}$ That should not be controversial at all. But in the context of the Service's current enforcement paradigm, the hypothetical advertisement, even funded entirely by a non-501(c)(3) organization and explicitly requesting non-deductible contributions, would be a breach of the Campaign Intervention Ban. ${ }^{84}$ While the Service has stated that it permits certain campaign-intervention activities by a 501(c)(4) organization even if that organization had been created by a 501(c)(3) organization and is affiliated with it, these permissible activities do not include the communication of the charity's views about candidates. ${ }^{85}$ From the Service's perspective, the

${ }^{82}$ It is beyond the scope of this article to discuss whether the proper way to structure an affiliation between a 501(c)(3) and a non-50(c)(3) organization is through the use of a $501(\mathrm{c})(4)$ organization, a 527 organization, or some combination of the two.

83 See supra notes 22-23 and accompanying text. At least two commentators have proposed avoiding attribution problems by eschewing 501(c)(3) status and reorganizing as either a $501(\mathrm{c})(4)$ organization or a taxable entity. See Cook, supra note 27; Hatfield, supra note 27.

${ }^{84}$ The Revenue Ruling does not deal explicitly with a non-501(c)(3) communicating a message that it expressly attributes to a 501(c)(3) organization, but the Ruling's focus on attribution makes it possible to conclude that such behavior would be prohibited. Rev. Rul. 2007-41, 2007-25 I.R.B. 1421. Interestingly, the only discussion of collaboration between 501(c)(3) organizations and non-501(c)(3) organizations is in Category six, which deals with so-called "business activity." This section applies to "selling or renting of mailing lists, the leasing of office space, or the acceptance of paid political advertising." $I d$. The Ruling specifies that in such situations it is not sufficient for an organization to show that such services were provided to a candidate for "a fee that is comparable to fees charged by other similar organizations." Id. Rather, multiple factors must be examined with the goal of determining if the organization is acting with complete neutrality as between candidates. The implication is that recovering the cost is not the important issue attributing a preference to a $501(\mathrm{c})(3)$ organization is.

${ }^{85}$ See supra note 7 and accompanying text; Treas. Reg. 1.501(c)(3)-1(c)(3)(iii) (2008). Erika Lunder and L. Paige Whitaker summarized the Service's position with regards to activities by charities as follows: "[i]n many situations, the activity is permissible unless it is structured or conducted in such a way that shows bias towards or against a candidate." ERIKA Lunder AND L. PAige Whitaker, Cong. Res. SERV., Order Code RL34447, CHURCHES AND CAMPAIGN ACTIVITY: ANALYSIS UNDER TAX and CAMPaign Finance Laws, at CRS-3 (Apr. 14, 2008). In Thomas \& Kindell, supra note 72 , at 264 , the Service stated that the actions of a $501(\mathrm{c})(4)$ organization in 
advertisement would still breach the Ban because it identified The Church at Pierce Creek as the author of the communication. ${ }^{86}$ And it is immaterial whether any of the church's funds were used to pay for it. $^{87}$

Under the Service's attribution paradigm, the affiliateorganizations solution - which was essential to the Supreme Court's holdings in TWR, Rust $v$. Sullivan and even Branch Ministries - is arguably incapable of providing 501(c)(3) organizations with a mechanism to engage in protected speech. ${ }^{88}$ Thus, under the Service's interpretation of the Ban a charity that wishes to engage in

conducting campaign-intervention activities would not be imputed to its 501(c)(3) parent unless the 501(c)(4) uses the 501(c)(3)'s "resources or assets." However, the guidance goes on to state that "[a]n important asset of an IRC 501(c)(3) organization is the time of its officers and directors." Therefore, the guidance concludes, such directors and officers should not direct the political campaign activities of the 501(c)(4) subsidiary. Even without the express prohibition on attributing speech to the 501(c)(3) parent, this ban on direction would make it difficult or impossible for a 501(c)(4) to communicate on behalf of its 501(c)(3) parent, since the parent is prohibited from acting through its directors to authorize the subsidiary to speak on its behalf. As for section 527 organizations, the IRS has taken the position that "if [a 501(c)(3) organization creates a separate segregated fund under section 527 of the Code and] the separate segregated fund conducts [campaign intervention] activities, [such] activities will be imputed to [the section 501(c)(3) organization] and [the organization's] exempt status as an organization described in section 501(c)(3) will be revoked." I.R.S. Gen. Couns. Mem. 39,694 (Feb. 1, 1988). See, also, I.R.S. Tech. Adv. Mem. 200446033 (Nov. 12, 2004) ("[section 501(c)(3) organizations] may not... establish political action committees").

${ }^{86}$ See Rev. Rul. 2007-41, 2007-25 I.R.B. 1421.

${ }^{87}$ See Elizabeth J. Kingsley, Election-Year Activities - The Good, The Bad, and the Vast Expanse of Gray, 19 TAX'N OF EXEMPTS 14, 14 (2008) (noting that "a statement of endorsement, even if no expenditure is involved, will be considered campaign intervention."). As discussed infra at Part $\mathrm{V}(\mathrm{B})(3)$, an attribution or endorsement may inherently involve the expenditure of funds, since it implicates the charity's "credibility."

${ }^{88}$ Under the Service's attribution paradigm, a charity could possibly avoid attribution problems if the advertisement attributed itself to a 501(c)(4) organization that communicated its association with the charity, for example, by using the charity's name in its own name. The Service has recently signaled its acceptance of certain types of implicit attribution in the context of related organizations in order to comply with the constitutional imperative stated in TWR. See Memorandum from Marsha Ramirez, Dir., Exempt Orgs. Examinations, Dep't of the Treasury, to All EO Revenue Agents, Political Campaign Activity on the Internet (July 28, 2008). But in doing so, the Service is stretching its attribution paradigm far, in effect accepting implicit attributions in certain contexts while arguing that attribution is generally a facts and circumstances test. It is this confusion that the expenditure paradigm advanced in this article seeks to avoid. 
constitutionally protected speech must forego 501(c)(3) status, and thereby lose its ability to receive tax-deductible contributions, even for charitable purposes. No court has held that forcing an organization to give up its 501(c)(3) status entirely in order to engage in such speech - even through an affiliate - is an adequate alternative channel. ${ }^{89}$ That is because giving up 501(c)(3) status goes beyond what is reasonably necessary to advance the legitimate government interest in expenditure equity, and is therefore an "undue burden."

Thus, if the Service wants to enforce the Ban within constitutional limits, it has a problem because all that is justified by the government's interest in expenditure equity is prohibiting a $501(\mathrm{c})(3)$ organization from using its own funds for campaign intervention. In order to solve this problem, the Service would have to give up its simple attribution analysis and ask a new question: were any of the charity's funds used in a campaign-intervention communication?

\section{V. "VALUATION" UNDER AN EXPENDITURE PARADIGM}

To this point, I have discussed two propositions: (1) that the Constitution requires that there be a legally permissible means for 501(c)(3) organizations to engage in campaign-intervention speech without being forced to forgo entirely the benefits of 501(c)(3) tax exemption; and (2) that the Service currently interprets the law in such a way as to prohibit such speech by a 501(c)(3) organization, even if funded by a non-501(c)(3) affiliate.

If these propositions are true, then the Service ought to adopt an enforcement paradigm that avoids the constitutional problem, and to do so, it must adopt some sort of expenditure paradigm. ${ }^{90}$ But given Congress's obvious interest in advancing expenditure equity to the fullest extent possible, the Service should try to adopt an enforcement paradigm that ensures that no tax-deductible funds are used for

${ }^{89}$ As discussed supra note 63, arguably the most burdensome statutory framework the Court has ever approved is the "program integrity" regime in Rust $v$. Sullivan, which required that governmentally-subsidized activities and non-subsidized activities take place in separate places with separate employees. For the reasons discussed supra note 63, I think such restrictions are not justified in the context of the Ban.

${ }^{90}$ Of course, Congress could make statutory changes to advance expenditure equity goals without running afoul of the Constitution. The easiest way to do this would be if Congress made all campaign intervention contributions, whether to 501(c)(3) organizations or directly to candidates, tax deductible. It would thereby level the playing - so to speak - by making all campaign-intervention expenditures made with pre-tax rather than post-tax dollars. 
campaign-intervention purposes. If the Service were to try to adopt an enforcement paradigm that balanced these interests, it would face a significant hurdle: preventing the expenditure of tax-deductible funds requires the adoption of accounting procedures - really valuation methods - to identify what constitutes an "expenditure" of funds for campaign-intervention purposes. Anything less would under-serve the government's interest in expenditure equity.

As discussed above, scholars have previously addressed the affiliate organization solution, often pointing out that the Service's attribution paradigm makes it impossible for organizations to use affiliates to engage in campaign intervention. ${ }^{91}$ In addition, commentators have generally not been enthusiastic about the use of affiliates as a potential way to permit the government to pursue its legitimate expenditure equity concerns while still permitting 501(c)(3) organizations to engage in constitutionally protected speech. ${ }^{92}$ Part of their hesitation may well originate in their concerns regarding the valuation exercise that would be required to determine how much any specific campaign intervention act "costs."

${ }^{91}$ See, e.g., Carroll, supra note 4, at 235 ("It is possible, moreover, that the Treasury would attack the dual structure under the circumstances involved and move to impute the campaign activity to the charity."); Chisolm, supra note 9, at 328 ("No effective alternative avenues for nonsubsidized expression of campaign-related political opinion are available to a section 501(c)(3) organization."); Hatfield, supra note 27 , at 146 (dismissing the affiliate organization solution because "the church's pastor still would not be able to endorse a candidate from the pulpit"); Kemmitt, supra note 9, at 173 ("[C]ommunications from the [affiliate] could not be communications from the church itself."); Samansky, supra note 9, at 44 ("Formation of a related organization, which the church might use for the dissemination of all political statements, would typically not be a feasible option."); Totten, supra note 9 , at 314-15 ("This alternative, however, fails for at least two reasons ....").

${ }^{92}$ Some commentators have focused on the administrative burdens of creating a separate organization to fund campaign-intervention speech. See, e.g., Carroll, supra note 4, at 235 ("Of course, even if the Service were to permit it, this would not be a viable option for the vast majority of churches and other charitable groups, which may have no reason or desire to create a section 501(c)(4) lobbying affiliate or no prospect of raising sufficient nondeductible funds to support a separate organization."). Some of these difficulties may be real (for example, campaign intervention would necessarily involve accounting for campaign-intervention expenditures and keeping accurate records), but some of the administrative difficulties may be exaggerated or created by the attribution paradigm.

${ }_{93}$ There are many examples of the abuse that exists in areas in which the Code requires taxpayers to determine the value of property that is difficult to appraise, and the Service's efforts to combat such abuse are often ineffective. For that reason, I propose in my next section valuation safe harbors that could be promulgated by the Service to avoid exactly that situation. But, for the reasons discussed herein, such safe 
insulate campaign intervention speech from the subsidy provided to 501(c)(3) organizations, then whatever method is used to determine how much must be paid by the non-(c)(3) affiliate must be sufficient to negate all of the subsidy.

\section{A. Current Proposals Insufficiently Address Expenditure Equity: De Minimis Solutions and Marginal Cost Theories}

Current proposals offered by commentators or legislators either fail to adopt an expenditure paradigm at all, or fail to advance a method that sufficiently advances the interests of expenditure equity. Some proposals are best described as de minimis solutions, in that they carve out some specific types of campaign-intervention activities that are viewed as least likely to permit the types of abuse that the Ban is purported to be most concerned with. ${ }^{94}$ Many of these proposals (notably, all of the proposals advanced by legislators except one) apply only to churches, and leave all other 501(c)(3) organizations without any solution. ${ }^{95}$

For example, The Religious Freedom Act of 2006 and 2007 would permit churches unlimited campaign intervention speech if such speech took place "in the theological or philosophical context of such organization. ${ }^{, 66}$ The Houses of Worship Free Speech Restoration Act of 2005 would permit churches to engage in campaign intervention

harbors should be theoretically linked to an adequate valuation analysis.

94 Although it has apparently moved away from such an analysis, the Service has previously issued guidance that suggested that it would ignore de minimis violations of the Ban. See, e.g., a discussion of such guidance in Carroll, supra note 4, at 240; Klapach supra note 9, at 531-32. Some commentators have pointed out that the current state of Service enforcement (at least until 2000) was so lax that it amounted to - at best - the application of a de facto de minimis standard. See, e.g., Carroll, supra note 4, at 227; Mayer, Grasping Smoke, supra note 64, at 4 (describing Service enforcement as "spotty at best"), 14 (noting significant instances of noncompliance).

${ }^{95}$ See supra note 11. De minimis theories that provide solutions only for churches present potential constitutional issues of their own. It is beyond the scope of this article to address Establishment Clause arguments against proposed solutions that permit churches but not non-religious 501(c)(3) organizations to engage in campaign intervention, but such arguments could be made. See, e.g., Ira C. Lupu, Threading Between the Religion Clauses, 63 LAW \& CONTEMP. ProBs. 439 (2000). Even short of such arguments, solutions that carve out an exception for churches fail to address the free speech concerns that plague non-religious 501(c)(3) organizations by ignoring the political speech rights of all organizations.

${ }^{96}$ Religious Freedom Act of 2007, S. 178, 110th Cong. (2007); Religious Freedom Act of 2006, S. 3957, 109th Cong. (2006). 
speech "during religious services or gatherings." The American Jobs Creation Act of 2004 includes a provision that would permit churches to engage in campaign intervention speech four times or less, so long as such speech was unintentional. ${ }^{98}$ Other proposals have similarly attempted to provide some room for churches to engage in campaign intervention, so long as the amount and context were limited. ${ }^{9}$ However, because these proposals permit campaign-intervention by 501(c)(3) organizations using tax-deductible funds, they fail to fully address the concerns of expenditure equity, even if they permit only limited amounts of intervention and only by specific types of organizations. $^{100}$

Other commentators have adopted what could be called "marginal cost" paradigms. A marginal cost is one that would not have been incurred but for campaign intervention motives. For example, if a church took out an advertisement decrying Bill Clinton's policies, and urging the public to vote against him, the fees paid to the newspaper are marginal costs. The postage to send the advertisement copy to the newspaper is a marginal cost. The salary of the minister or church employee who wrote the advertisement is not a marginal cost because the salary would have been paid in the same amount whether the employee had written the advertisement or not. Some commentators have argued that campaign-intervention should be permitted when no marginal, "incremental" or "third party" costs are

${ }^{97}$ Houses of Worship Free Speech Restoration Act of 2005, H.R. 235, 109th Cong. (2005).

${ }_{98}$ American Jobs Creation Act of 2004, H.R. 4520, 108th Cong. $\S 692$ (as introduced in the House, June 4, 2004).

${ }^{99}$ See generally, legislative proposals cited supra note 11. See also, Buckles, Peep, supra note 9, at 1108-09 (proposing that "independently controlled charities" be permitted to make unlimited campaign expenditures and that non-independent charities be permitted to make "any oral communication made primarily between an organization and its members in person"); Totten, supra note 9, at 321-23 (arguing that oral communications at church gatherings should be permitted); Ellen Aprill, Letter to Various Government Officials Dated November 29, 2005 (stating that "it is better to err on the side of allowing rather than denying political speech" and proposing four safe harbors for (1) discussions that do not refer to specific policies; (2) statements by an individual made with a disclaimer that the person is not speaking for the organization; (3) statements that do not identify a candidate; and (4) statements made outside an election cycle).

${ }^{100}$ For a systematic discussion of why de minimis solutions violate principles of tax fairness, see generally Richard J. Wood, Pious Politics: Political Speech Funded Through I.R.C. $\$ 501(c)(3)$ Organizations Examined Under Tax Fairness Principles, 39 ARIZ. ST. L.J. 209 (2007). 
incurred. ${ }^{101}$ Others have proposed that the law be changed to permit campaign intervention under certain limited circumstances, so long as no marginal costs are incurred. ${ }^{102}$

For example, Allan Samansky recently argued that churches (but not other 501(c)(3) organizations) should be encouraged to participate in the electoral system as an "effective counterweight to moneyed interests that try to influence the voting public." $103 \mathrm{He}$ proposes that "churches and religious leaders should have virtually

101 See, e.g., Caron \& Dessingue, supra note 30, at 193 (discussing the "additional cost incurred as a result of what the IRS might characterize as 'political activity' in a sermon"); Feld, supra note 9, at 938 ("if the church spends no funds to promote the candidate and the use of its property incurs only nominal expense, the activity arguably does not entail the expenditure of tax-subsidized dollars in the political campaign"); Kemmitt, supra note 9, at 177 (arguing that if only expenditures were banned, "[c]andidate endorsements from the pulpit would be clearly permissible"); Elizabeth J. Kingsley, Praise the Lord and Pass the Voter Guides, 18 TAX'N OF EXEMPTS 278 (2007) ("A limited exception for religious speech where there is no measurable expenditure of funds has the strong appeal of taking the tax man out of the pulpit."); see also, I.R.S. Priv. Ltr. Rul. 200446033 (June 14, 2004) (in which the IRS rejected - by ignoring - the taxpayer's argument that no expenditure had been made by a 501(c)(3) organization because all "incremental" costs had been reimbursed by a section 527 organization created by a section $501(\mathrm{c})(6)$ affiliate of the 501(c)(3) organization); I.R.S. Priv. Ltr. Rul. 96-09-007 (Dec. 6, 1995) (holding that because a fund raising letter constitutes campaign intervention, "[a]t the least, the cost of publishing and distribution of the subject letters, and related incidental expenses, are political expenditures as defined in section 4955(d)(1)" without discussing the impact of the fact that the letter was sent out by a for-profit fundraising firm, which bore the costs described above in exchange for a percentage of the funds raised).

${ }^{102}$ Commentators who propose adopting the categories and definitions from campaign-finance law are, in effect, arguing for a "marginal cost" definition of political expenditures, even if they are not conscious of it. See, e.g., Ablin, supra note 9, at 583-84; Chisolm, supra note 9, at 362; see also, Kemmitt, supra note 9; Mayer, Grasping Smoke, supra note 64, at $\mathrm{n} .5$ (discussing the proposals of others). A discussion of how expenditures are defined, and therefore what is permitted and prohibited under FECA's "ban" on corporate expenditures, is beyond the scope of this article. However, a discussion of how the standards enforced by the FEC interact with those enforced by the Service can be found in Lloyd H. Mayer, The Much Maligned 527 and Institutional Choice, 87 B.U. L. REv. 625 (2007) [Hereinafter, Mayer, Choice]; Elizabeth J. Kingsley \& John Pomeranz, A Crash at the Crossroads: Tax and Campaign Finance Laws Collide in Regulation of Political Activities of TaxExempt Organizations, 31 WM. Mirchell L. Rev. 55 (2004); Ezra W. Reese, The Other Agency: The Impact of Recent Federal Law Enforcement on Nonprofit Political Activity, 58 EXEMPT ORG. TAX REV. 131 (2007).

${ }^{103}$ Samansky, supra note 9, at 150. 
complete freedom to communicate with their congregations, ${ }^{, 104}$ but that communications to non-members should continue to be absolutely prohibited. ${ }^{105}$ Expenditures for campaign intervention that would not have been made but for campaign intervention motives are still completely prohibited under Samansky's proposal. ${ }^{106}$

While it is intuitively appealing to suppose that no expenditure is made unless an incremental cost is incurred, a marginal cost theory is insufficient to account for the benefit obtained by a 501(c)(3) organization on account of its receipt of subsidized funds. ${ }^{107}$ That is because an organization may use expenditures made with subsidized funds to support its campaign-intervention activities, but without making any marginal expenditure. For example, if an organization uses subsidized funds to engage in certain activities, and those

${ }^{104}$ Id. at 165 .

10.5 Interestingly, Samansky argues that the only limitation regarding "sermons and routine communications" should be that no "official endorsement" should be permitted, since the purpose of endorsements is allegedly to communicate the church's views to outsiders. See Samansky, supra note 9, at 166. Unfortunately, stopping short of permitting endorsements potentially prevents Samansky's proposal from resolving the constitutional concerns. If the constitutional analysis suggested in this article is correct, then it is at the heart of the First Amendment protection that an entity be permitted to communicate its own views on candidates, and that is exactly what an official endorsement is. Thus, solutions that stop short of permitting a 501(c)(3) organization from making an endorsement (even an "official" endorsement) do not resolve the constitutional issue. See also, James, supra note 9, at 410 (proposing that Congress amend the Code to permit small churches to engage in campaign intervention with funds raised specifically for those purposes, but continuing to argue that such churches be permitted to endorse candidates only "at non-religious events").

106 See Samansky, supra note 9, at 165 (campaign-intervention activities prohibited if they "involve a direct expenditure of funds").

${ }^{107}$ Chris Kemmitt has recently proposed focusing on expenditures, but seems to have implicitly adopted a marginal cost method of identifying such expenditures. See Kemmitt, supra note 9, at 176-77. His proposal has therefore been criticized for treating as free, and therefore permitting, activities like "[c]andidate endorsements from the pulpit." Wood, supra note 100, at 229. Wood argues that such endorsements potentially involve "three specific and discrete expenses" (space, media, and speaker salary). Id. Likewise, Johnny Rex Buckles calls Kemmitt's proposal to ban only "incremental" costs problematic since "the proposal is ambiguous, and quite possibly unworkable." Buckles, Peep, supra note 9, at 1099 n.136. But notwithstanding his criticism of Kemmitt, Buckles proposes that "non-independent" charities be prohibited only from making campaign-intervention expenditures, without exploring what would constitute an expenditure. See Buckles, Peep, supra note 9, at Appendix. See, also, Feld, supra note 9, at 939 (arguing that "[f]ocus on the use of funds seems warranted, to prevent the diversion of government subsidy from exempt purposes to political activity" but assuming that a church endorsement is free). 
activities serve both campaign-intervention and non-campaignintervention purposes, the fact that the campaign intervention activities produce no increased marginal costs do not negate the effects of the subsidy. Therefore, "marginal cost" theories or proposals are inadequate to serve as the basis for a regulatory paradigm that fully advances the government's interest in expenditure equity.

\section{B. A Sufficient Theory Must Account for Allocation of Expenditures that Advance Campaign-Intervention Objectives}

\section{Allocation of Costs}

If the various marginal cost and de minimis theories are insufficient to account for the full benefit received by 501(c)(3) organizations on account of the deductibility of donations, a sufficient theory would ensure that no funds obtained on a tax-deductible basis were used for campaign-intervention purposes. In effect, such a theory must provide a means to value "costs" associated with the campaignintervention and non-campaign-intervention aspects of shared activities, so that the correct proportion of shared expenditures related to such activities could be allocated between the two aspects. When such allocation accounting has been performed, then the organization(s) could ensure that campaign-intervention expenditures were paid for by the non-501(c)(3) affiliate organization.

As discussed above, the challenges of an adequate cost allocation theory can be illustrated by thinking about the example of a minister endorsing a candidate during a regularly-scheduled worship service in a 501(c)(3) church. ${ }^{108}$ Commentators have noted that when a minister communicates an endorsement, his or her salary is paying for both campaign-intervention and non-campaign-intervention activities. ${ }^{109}$

${ }^{108}$ This article focuses on actual endorsements to avoid discussing the border between campaign-intervention and non-campaign-intervention activities, which are beyond the scope of this article. But, of course, a minister's words at a regularlyscheduled worship service could constitute campaign intervention even if such words were not an outright endorsement. If the words constituted campaign-intervention, then the analysis that applies to an endorsement would apply equally.

${ }^{109}$ This type of cost allocation has enough intuitive appeal that it has been advocated, at least implicitly, by several commentators on the Ban, although no one has attempted to describe a method by which such allocation should be made. See, e.g., Carroll, supra note 4, at 235 ("[T]he clergy ... should be able to comment from the pulpit ... or speak out for or against candidates as long as their compensation ... and any other associated expenses are paid from the [non-501(c)(3)] affiliate's 
But even something as seemingly simple as allocating the cost of the minister's paid time would potentially involve numerous decisions and calculations. The first decision would be whether to treat all of the minister's time equally, or whether to treat the time he spends actually speaking to his congregation as more (or less) valuable than time he spends counseling, teaching, studying or anything else his or her job entails. Assuming that it is reasonable to treat all time equally, then one would need to tally up all his time, divide by his salary and benefits and calculate the amount of time spent delivering his message, ${ }^{110}$ researching and preparing that message, and consulting with lawyers and accountants about the tax implications of the speech. The resulting cost under such an analysis would likely be small. The proper share of other current expenditures, like publicity, space rental, and the cost of consultants may also have to be allocated.

Some commentators have offered the opinion that "shared" activities, like political speech in a sermon, must be completely banned or entirely permitted because of "severability" problems. They argue that a communication from a minister in her sermon cannot be "separated" into the words of the 501(c)(3) church and the

income ...."); Chisolm, supra note 9, at $358 \mathrm{n} .216$ ("Of course, expenses would have to be properly allocated."); Totten, supra note 9, at 322 ("Of course, almost any oral or written communication made by a religious leader who draws a paycheck from the congregation conceivably carries a price tag."); Wood, supra note 100, at 237 ("While a 501(c)(3) religious organization might own its own broadcasting facilities and equipment, their cost can still be allocated among the individual uses to which the facilities or equipment are put.... [This can be done through] detailed amortization schedules for church-owned media assets plus allocation of personnel and overhead expenses.").

${ }^{110}$ In determining the length of time devoted to delivering the message, one would have to decide whether an entire sermon in which an endorsement has been made is at issue, or whether the portion of the sermon devoted to actually endorsing the candidate can be separated out. In I.R.S. Priv. Ltr. Rul. 200437060 (June 7, 2004), the Service found that a broadcast by a 501 (c)(3) church constituted campaign intervention, and it imposed the section 4955 excise tax on the marginal costs associated with the entire broadcast. Similarly, in its investigation of the NAACP, the Service requested an accounting of the total of the expenditures made for the convention at which the allegedly campaign-intervention speech was made. Lloyd Mayer, who represented the NAACP, concluded that it was planning to consider all expenditures made to hold the convention as "expenditures" for the purposes of calculating excise taxes, rather than just that portion of the convention during which the speech at issue was made. See Mayer, Grasping Smoke, supra note 64, at 38 nn.129-30 and accompanying text. Richard Wood has argued that not only the time spent giving the sermon should be considered, but also expenses associated with any entertainment given at the service at which an endorsement is made. See Wood, supra note 100 , at $237-38$. 
words of its non-501(c)(3) affiliate. ${ }^{111}$ When a minister speaks at a sermon, her words are essentially unitary, and it is meaningless to separate them between campaign-intervention and non-campaignintervention categories. As a hermeneutic matter, this may well be true. The arguments the minister makes about what God commands in terms of moral action may be unitary and flow inexorably from a single source, whether the command is to love one's neighbor or to vote for John McCain. Likewise, it may be meaningless for the minister to try to attribute the two components (campaign intervention and non-campaign-intervention) to different sources. And, in fact, the Service has taken the position that the words of a minister at an "official" function of a 501(c)(3) organization will be attributed to the 501(c)(3) organization no matter what the minister says or does. ${ }^{112}$ So, from an attribution perspective, certain activities may well be "inseparable."

But if the question is not attribution but allocation, then arguments about "inseparability" make less sense. If one assumes that campaign-intervention words cannot be separated from noncampaign-intervention words within any single act of discourse (like a sermon) but that they can be separated from linked ideas expressed in separate discourses, then the hermeneutic problem is solved. More importantly, so long as an adequate allocation method can be developed, the mechanics of allocation should not be challenging. Allocation by definition means separating a single expenditure into component parts. For example, imagine that one concluded that the salary of the minister had to be allocated between campaign-

${ }^{111}$ See Buckles, Reply, supra note 9, at 1105 ("[A] pastor carries the pulpit with him wherever he goes ...."); Caron \& Dessingue, supra note 30, at 193 ("The utility of this approach, however, depends on the severability of the Exempt Organization's [political] activities. Certain church activities that may be characterized by the IRS as political activity are not severable, e.g., teaching and preaching functions that normally take place during worship services .... There is no practical means by which [these activities] can be delegated to a section 501(c)(4) affiliate."); Klapach, supra note 9, at 515 ("[T] he severance of political expression from a religious organization's otherwise exempt activities would be impossible when a religious leader gives a sermon or other religious instruction."); Ryan, supra note 30, at 90-91 ("However, it is not possible to segregate sources of funding when a religious organization adopts a position that it will not distribute communion to members who vote in a particular way.").

${ }^{112}$ The Service has taken the position that it is impossible for a minister to effectively attribute his speech to anything other than the 501(c)(3) organization if he is speaking at an "official" function of the organization. See Rev. Rul. 2007-41, 2007-1 C.B. 1421. 
intervention and non-campaign-intervention purposes, and imagine that one had developed a method for reasonably allocating. Once the allocation was complete, the actual mechanism of paying from separate sources - one a 501(c)(3) and one a non-501(c)(3) - can be accomplished either by having each organization cut the minister a check for his salary, or, if it is easier, for the minister to receive his salary from one source (say, the 501(c)(3) organization), which would then be reimbursed by the other. This reimbursement method would presumably be possible for any of the costs that should properly be allocated between organizations. Determining the amount of reimbursement is not a simple matter, but accomplishing the mechanics of reimbursement can be simple indeed. It is just a matter of accounting. ${ }^{113}$

\section{The General Problem of "Capital Assets"}

If allocating readily identifiable costs, like the speaker's salary, is complicated, there are other potential costs that are even more difficult to allocate, some of which may not be immediately apparent. Take, for example, time spent by volunteers. The Service has commented that the time of an organization's (presumably volunteer) board is an "important asset." volunteer's actions cost nothing to the organization, no tax-deductible funds have been expended. And, after all, a person is permitted to volunteer directly with a candidate to benefit his or her campaign. From the perspective of expenditure equity, it appears that there is no justification for prohibiting a person from providing volunteer service to his or her church, which is then used to benefit a candidate. Volunteering through a church instead of individually does not appear to "tilt" the campaign-finance playing field.

But that analysis is only true to the degree that no tax-deductible funds have been expended in connection with the volunteer's actions. While the time of volunteers may not involve any "direct" costs, like salary, there may be costs associated with volunteers' association with the organization nonetheless. For example, the organization has

${ }^{113}$ As is discussed infra at Part $\mathrm{V}(\mathrm{B})(2)$ and (3), the ability of non-501(c)(3) organizations to reimburse 501 (c)(3) for costs incurred in the past is important to imagining how certain "hidden costs" discussed infra could be allocated. For a discussion of the mechanics of reimbursement, see Elizabeth J. Kingsley, Shared Payroll Considerations in Structuring Cost-Sharing Arrangements, 19 TAX'N OF $^{\text {' }}$ EXEMPTS 43 (2007).

${ }^{114}$ See Thomas \& Kindell, supra note 77, at 264. 
presumably spent money in the past to gather volunteers together, to organize them, and to communicate with them. These expenditures were presumably made with tax-deductible contributions. In this way, an organization's volunteers may constitute a sort of "hidden" capital asset, in that expenditures may have been made over time to create or enhance their value to the organization. Even though the organization doesn't pay them anything, it has invested in the past in their acquisition and cultivation. ${ }^{115}$ Because the organization has used taxdeductible contributions to acquire and cultivate its volunteers, an argument could be made that the principles of expenditure equity are violated when volunteers of a 501(c)(3) organization are used for campaign-intervention activities. But what is less clear is how an organization could identify the proper allocative share of these historic expenditures in order to ensure that a non-501(c)(3)'s funds are used to reimburse the 501(c)(3) for such expenditures.

Other, more recognizable, capital assets may also be implicated in the campaign-intervention activities of 501(c)(3) organizations. For example, when a minister intervenes in a campaign during a worship service, the building in which the worship service takes place may be implicated. The building may have been purchased many years ago. For tax and accounting purposes, the church building may have been fully depreciated long ago. The remaining "cost" (really, cost basis) in the building may be zero. But still, at some point the church presumably used tax-deductible contributions to build or acquire the building. Permitting the organization (or its affiliate) to use it for free arguably violates the policy of expenditure equity. Thus, it appears that an adequate expenditure method would include some method of allocating both the current and the capital expenditures that support campaign-intervention activities.

\section{The Allocation of the Cost of an Organization's "Credibility"}

In this article, I have argued that the Service's attribution paradigm fails to limit the Ban to constitutional parameters. But that is not to say that the Service's intuition that attribution is important is

115 An even more concrete example of this type of "asset," is the membership or mailing list of an organization. The organization may have spent almost nothing specifically to compile it, but in some ways all the charitable activities that the organization has done (using tax-deductible contributions) are drawn upon in the creation of the list. These lists have been identified by politicians as having significant value, and the Service has directly addressed their proper treatment under section 501(c)(3). See Rev. Rul. 2007-41, 2007-1 C.B. 1421. 
misguided. Indeed, an argument could be made that the identity of the speaker of campaign-intervention speech is central to its proper treatment under an expenditure paradigm. This argument proceeds from the observation that the effectiveness - and therefore value of campaign-intervention speech may be directly linked to the identity of its speaker. Indeed, the very concept of an "endorsement" presupposes that the listener cares more about the credibility of the speaker than the content of the argument such speaker makes on behalf of a candidate. If the Service's position is that attribution is the key to campaign-intervention speech, then the question is whether this position can be incorporated into an expenditure paradigm so that the Ban can be enforced within constitutional parameters.

If an organization's building is a tangible example of a "capital" asset that may be implicated in a cost allocation method that attempts to accurately reflect the interests of expenditure equity, and its membership may be an example of a less tangible example, one could argue that the identity of the speaker gives rise to an even more abstract example of a capital asset. Whenever a view on a candidate can be attributed to an organization, the organization's credibility is implicated. An argument could be made that subsidized expenditures made by an organization over its entire history have served on some basis to enhance its credibility. Whatever it has spent its money on, that money has served to enhance the perceived legitimacy of the organization among its constituency. When it makes an endorsement, the organization draws upon this history of legitimacy. ${ }^{116}$

116 This "legitimacy" factor could be thought of in more familiar terms. It is generally accepted that an operating business is usually more valuable than the sum of the value of its operating assets. This excess value is usually attributed to a series of factors that defy easy valuation, often thrown together as "goodwill." Goodwill may include such intangible assets as the value of certain business processes and the value of the business's supply and distribution networks. But at least one component of goodwill (the one from which it gets its name) is the favorable impression among customers and suppliers that a business has created through its years of existence. This component of goodwill may be understood as the value of a business's "brand" or "name." Thomas and Kindell identify "goodwill" and "name" as organizational "assets" of a 501(c)(3) organization. See Thomas \& Kindell, supra note 77, at 261. To the best of my knowledge, the only scholar to explicitly recognize the value of the goodwill of an endorser is Johnny Rex Buckles, Peep, supra note 9, at 1098 n.135. The idea was first suggested to the author in conversation with Calvin Johnson. Others have arguably implicitly recognized such value. See, e.g., Samansky, supra note 9 , at 176 ("The cost of publishing [an endorsement] on the internet or sending a letter to parishioners is trivial relative to its effect. The impact of the message would be unaffected [by attribution to a non-501(c)(3) affiliate] because the Bishop's authority would still be behind it."). 
For example, if the Nature Conservancy spends the majority of its money preserving endangered lands, fighting for environmental causes, and raising the awareness of the public about environmental issues, then all or most of the money it spends on these activities is implicated when it makes an endorsement. The fact that it has conducted those other activities over the years with "subsidized" funds means that it has an unfair advantage when it finally decides to make an endorsement. In the popular parlance, it has spent years building "cultural capital," which it now "spends" for a campaign intervention purpose. If it has used subsidized funds to build its cultural capital, an expenditure equity problem has been created, unless the expenditure paradigm can account for the funds expended in creating such cultural capital.

It is conceivable that this issue is at the heart of the suspicion with which some commentators view campaign intervention by 501(c)(3) organizations. To the degree to which it seems impossible to formulate a theory (much less a method) by which a cost-allocation method would adequately account for the cost of creating a 501(c)(3) organization's credibility, an expenditure method seems doomed to undervalue campaign intervention by 501 (c)(3) organizations. ${ }^{117}$

This very brief discussion of the valuation problems inherent in crafting a regulatory paradigm adequate to meet the demands of expenditure equity has led to a few conclusions. First, expenditure equity requires that a valuation theory that is adequate to provide the basis for a reimbursement or cost-sharing regimen must attempt to track expenditures that have potentially been made with subsidized funds. Neither a de minimis nor a marginal cost theory can do that. Second, costs that are material to the analysis may be hard to identify. Finally, an argument could be made that costs (or a portion of those costs) associated with building an organization's credibility might be

117 In addition to the effect of the subsidy provided to $501(\mathrm{c})(3)$ organizations through the deductibility of contributions, there is an argument to be made that the Code - by setting certain organizations apart and permitting them to use the name "501(c)(3)" - provides a subsidy to the charitable sector in general. Lloyd Mayer has discussed the "halo effect," which he describes as the "disproportionate electoral effect" a charity may enjoy "because of the goodwill charities generally enjoy." Mayer, Grasping Smoke, supra note 64, at 22 . If the confidence placed in charities by the public is due (at least in part) to the regulatory apparatus that defines the actions permissible to charities, then it is possible to argue that this halo effect is created through a subsidy provided by the Code, but distinct from the subsidy provided by deductibility of donations. See also, Klapach, supra note 9, at 505 ("Knowing that the IRS monitors tax-exempt charities and that it will impose serious sanctions for a charity's misdeeds assures contributors of a charity's legitimacy."). 
implicated in an expenditure analysis that truly maximized the government's interest in expenditure equity. Thus, despite Justice Scalia's view that "one need not consult a CPA" to perform an allocative cost analysis, ${ }^{118}$ it is clear from the discussion above that finding a theoretically justifiable paradigm for such an allocation method may be difficult indeed.

What then should the Service do? If the constitutional analysis described herein is correct, then the Service needs to change its enforcement paradigm to permit some mechanism by which 501(c)(3) organizations can engage in campaign-intervention speech. If it wants to advance the government's interest in expenditure equity, it needs to recognize a method to do so that prevents funds raised on a taxdeductible basis from being used for such activities. The next section attempts to lay out two approaches that the Service may take to better match its enforcement of the Ban to the expenditure equity concerns that justify it, without becoming paralyzed by the practical problems of creating a perfect match.

\section{PROPOSED SOLUTIONS: MODELS FOR AN EXPENDITURE PARADIGM}

As I have pointed out, a de minimis rule is insufficient as a means of providing a sound theoretical basis for an enforcement paradigm by the Service. But that is not to say that the Service does not have significant latitude in crafting its guidance. So long as there is some mechanism that permits 501(c)(3) organizations from engaging in campaign-intervention activities without being "unduly burdensome," the Service may well avoid the constitutional problem. ${ }^{119}$ In order to advance the government's interest in expenditure equity, however, the Service should try to prevent, as much as possible, the use of goods or services that have been paid for with tax-deductible contributions for campaign-intervention activities.

${ }^{118}$ Hein v. Freedom From Religion Found., Inc., 127 S. Ct. 2553, 2581 n.4 (Scalia, J., concurring) (2007).

119 If a government agency must miss the mark in perfectly balancing the constitutional right to speech with a compelling governmental interest, First Amendment jurisprudence generally holds that it should err on the side of too much, not too little, protection of speech. See, e.g., FEC v. Wis. Right to Life, Inc., $127 \mathrm{~S}$. Ct. 2652 (2007). Therefore, the Service need not hit the nail exactly on the head, although it should craft its regulatory paradigm to miss the mark at the expense of expenditure equity and not speech. 
Above all, the Service needs to issue guidance that makes it possible for organizations to engage in protected speech while steering clear of prohibited activities. Thus, first, the Service should issue guidance that explains that, contrary to its prior position, attribution of campaign-intervention speech to a 501(c)(3) organization is not sufficient to constitute a breach of the Ban. Rather, the Ban prohibits only campaign-intervention expenditures by 501(c)(3) organizations. Second, the guidance should make it clear that a 501(c)(3) organization that wishes to engage in campaign-intervention activities may use non-501(c)(3) affiliates to fund such activities. Third, the Service should make clear that the concept of "expenditures" includes more than just those incremental costs identifiable under a marginal cost theory. Thus, allocations and reimbursements may be required, and such allocations or reimbursements must be made based on a reasonable method. Fourth, the Service should provide one or more safe harbor methods for reasonable allocation. ${ }^{120}$

This section contains two proposals for such a safe-harbor reasonable allocation method: one that attempts to provide a workable method for allocating expenditures of 501(c)(3) organizations and a second that attempts to graft onto that method an attempt to take into account expenditures made that have enhanced an organization's credibility. Both are simplifying methods that the Service could adopt as safe-harbors, presumptively constituting a reasonable allocation. The first is to model the allocation method on an existing one: the rules for allocating lobbying expenditures found in Treas. Reg. 1.162-28. This method has the benefit of being potentially familiar to taxpayers and to the Service, but - especially if endorsements are "capital intensive" activities - it has the weakness of potentially undervaluing the acts of 501(c)(3) organizations (and therefore insufficiently advancing the goals of expenditure equity). The second proposes a safe harbor for valuing speech by a 501(c)(3) organization that is wholly new. This second proposal is an attempt to address the argument that an organization's endorsement is much more valuable than would be calculated under the first simplification method. But this proposal has the weakness of being largely arbitrary in its valuation method.

${ }^{120}$ Many scholars (as well presumably as most charities) would favor some sort of bright-line rule. For an example, see Mayer, Grasping Smoke, supra note 64, at 31-36. 


\section{A. Allocation Using the Methods Approved Under Treasury Regulations 1.162-28}

As discussed above, the concept of expenditure equity assumes that taxpayers other than 501(c)(3) organizations are not able to make deductible campaign-intervention expenditures. ${ }^{121}$ And, in fact, the Code generally denies taxpayers the ability to deduct expenditures made for campaign intervention. For example, taxpayers engaged in a trade or business may not deduct campaign-intervention expenditures, even if such expenditures would otherwise be permitted as an ordinary and necessary business expense. ${ }^{122}$ If expenditure equity seeks to treat taxpayers alike with regard to campaign-intervention expenditures, then it would be logical for the non-deductibility of business taxpayers' campaign-intervention expenditures to provide a model for the non-deductibility of charities' campaign-intervention expenditures. ${ }^{123}$

Unfortunately, there is no guidance from the Service about how a business should determine which of its expenses are for campaignintervention purposes or how to allocate expenses between campaignintervention and non-campaign-intervention purposes. However, the Treasury Department has adopted regulations in a closely analogous area. In addition to making campaign-intervention expenditures nondeductible, the Code currently denies taxpayers the ability to deduct most lobbying expenditures, even if such expenditures would otherwise be deductible as business expenses. ${ }^{124}$ In the lobbying context, Treasury Regulations have been adopted that require that at

${ }^{121}$ See supra at note 29 and accompanying text.

${ }_{122}$ See I.R.C. $\S 162(\mathrm{e})(1)(\mathrm{B})$ ("No deduction shall be allowed ... for any amount paid or incurred in connection with ... participation in, or intervention in, any political campaign on behalf of (or in opposition to) any candidate for public office").

${ }^{123}$ As discussed supra note 102, several commentators have proposed limiting the Ban to instances in which an "expenditure" has been made under federal campaign finance law. A full discussion of the definition of campaign activity under the FECA, 2 U.S.C. $\$ \S 431-57$, is beyond the scope of this article, but suffice it to say that limiting the Ban to activities currently prohibited to corporations and labor unions under FECA would be significantly more permissive even than using section 162(e) as a model. It would also be logical to use as a model the allocation rules promulgated for use with the excise tax for excess lobbying by charities under section 4911 of the Internal Revenue Code. See Treas. Reg. $\$ 56.4911-3$ (1990). Applying these rules would produce a more permissive allocation methodology as well, which would therefore serve the interests of expenditure equity less fully than rules modeled on Treas. Reg. \& 1.162-28 (1995).

${ }^{124}$ See I.R.C. $\$ 162(\mathrm{e})(1)(\mathrm{A})$. 
least certain expenditures made for both lobbying and ordinary business purposes be allocated between the two uses according to a reasonable method. ${ }^{125}$ Despite differences in both context and subject matter, it is logical to attempt to adapt these regulations to the Service's need to find an adequate method for allocating expenditures of a 501(c)(3) organization between campaign-intervention and noncampaign-intervention purposes. Having gone through the formal process by which federal regulations are adopted, they reflect the reasoned opinion of the Treasury Department about proper allocation methods for a closely related purpose.

It is worth noting that the provision relating to lobbying expenditures has a generous statutory de minimis exception, which permits a taxpayer to deduct up to $\$ 2,000$ of "in house expenditures" in any year (so long as such expenditures would otherwise be deductible as an ordinary and necessary business expense). ${ }^{126}$ "In house" expenditures include any expenditure other than those paid to professional lobbyists or as dues to organizations that engage in lobbying on behalf of the taxpayer. ${ }^{127}$ Notably, the Code provides that "[i]n determining whether a taxpayer exceeds the $\$ 2,000$ limit under this clause, there shall not be taken into account overhead costs otherwise allocable to [lobbying] activities." 128 In other words, so long as a taxpayer does not hire a lobbyist, and so long as expenditures made to third parties for lobbying purposes do not exceed $\$ 2,000$, a taxpayer may deduct both its third-party payments and all of its overhead expenses that were incurred for lobbying purposes. In this context, the deduction of "overhead" expenses presumably means that no allocation would be necessary for the types of "shared" expenditures discussed above in section $\mathrm{V}(\mathrm{B})(1)$, like salaries, much less any of the less obvious costs discussed above in sections $V(B)(2)$ and (3). Thus, in the language adopted in this article, the statutory de minimis exception adopts a marginal cost method for measuring expenditures, and permits unlimited activity, so long as the marginal cost of all such activity is less than $\$ 2,000$ (and so long as professional lobbyists are not hired). This de minimis exception provides the opportunity for an organization to deduct the cost of quite a lot of lobbying activities, so long as its payments to third parties are modest. For the reasons discussed above, such a generous de minimis

${ }^{125}$ See Treas. Reg. $§ 1.162-28$. These allocation rules apply to lobbying activities, not campaign-intervention activities.

${ }^{126}$ See I.R.C. $\$ 162(\mathrm{e})(5)(\mathrm{B})$.

${ }^{127}$ See I.R.C. § 162(e)(5)(B)(ii).

${ }^{128}$ I.R.C. $\S 162(\mathrm{e})(5)(\mathrm{B})(\mathrm{i})$. 
exception would not fully advance the government's interest in expenditure equity, and so a solution that adopted it would not solve the problem posed in this article.

However, if the statutory de minimis exception is ignored, there is the possibility that the section 1.162-28 Regulations could be used as a model for enforcement of the Ban. If an organization does not fall within the statutory de minimis exception, then in addition to being barred from deducting its third-party expenditures that exceed $\$ 2,000$, the taxpayer must allocate certain overhead costs between lobbying and non-lobbying purposes. ${ }^{129}$ These allocable overhead costs expressly include salaries under the subcategory "labor costs," as well as less obvious expenditures such as "depreciation, rent, utilities, insurance, maintenance costs ... and other administrative department costs," under the subcategory of "[g]eneral and administrative costs." $" 130$

Generally, the Regulations hold that any reasonable method may be employed to allocate costs between lobbying and non-lobbying activities, but they also provide three simplified methods that a taxpayer may use to avoid the complication of devising its own reasonable method. ${ }^{131}$ For example, a taxpayer may use the "ratio" method, under which the taxpayer creates a ratio, the numerator of which is the total amount of "lobbying labor hours" and the denominator is "total labor hours." This ratio is then multiplied by the company's "total cost of operation." The sum is then added to "thirdparty costs" to reach total lobbying expenditures for the taxpayer for the year. ${ }^{132}$ In other words, under the ratio method, non-third-party costs are determined as a flat ratio based entirely on employee hours devoted to lobbying activities. ${ }^{133}$ It is notable that "total cost of

${ }^{129}$ Treas. Reg. $\$ 1.162-28(\mathrm{c})$.

${ }^{130}$ Id.

131 See Treas. Reg. $\S \S 1.162-28(d),(e)$, (f). See generally, T.D. 8602, 1995-2 C.B. 15.

${ }^{132}$ See Treas. Reg. $\$ 1.162-28(d)(1)$. Third-party costs are loosely analogous to those costs that would be considered under a "marginal cost" method, as discussed supra Part V(A).

${ }^{133}$ The Regulations provide an additional de minimis exception that applies to the calculation of the number of employee hours devoted to lobbying activities. In calculating the amount of time employees collectively spend on lobbying activities, any employee who spends less than five percent of her time on lobbying does not have to be counted, in effect permitting the taxpayer to round such employees' lobbying time down to zero, see Treas. Reg. $\S 1.162-28(\mathrm{~g})(1)$, with the caveat that any time spent by an employee on "direct contact lobbying" (speaking directly to lawmakers) cannot be rounded down to zero. See Treas. Reg. \& 1.162-28(g)(2). This 
operations" includes just what it says, and therefore would presumably include capital expenditures and any expenditure made to build an organization's credibility.

The ratio method, like the other two methods discussed in the Regulations, provides a simplified way of dividing a taxpayer's total expenditures between lobbying and non-lobbying activities, by relying on total employee labor hours devoted to lobbying activities as a stand-in for total investment in lobbying activities. If similar allocation rules were adopted for campaign-intervention activities by 501(c)(3) organizations, charities would be able to calculate how much of their expenditures would have to be reimbursed by a non-501(c)(3) affiliate, in effect - at least theoretically - nullifying the effect of the deduction for contributions to the 501(c)(3). But this method is only effective to the degree that employee labor hours are an adequate substitute for actual expenditures.

The calculation would begin in the same way as the ad hoc salary calculation described above $\mathrm{e}^{134}$ - by calculating the total amount of time spent by the minister in making the campaign-intervention sermon. In the hypothetical presented above, we assumed that the minister spent three hours in all. Under the ratio method, these three hours would be added to hours spent by other paid employees. As for volunteers, such as volunteer board members who may have been involved in the decision of whether and whom to endorse, they would presumably not fall under the category of "employees," and their time would be ignored no matter how much they spent on campaignintervention activities. But once the ratio of employee hours was determined (say, 3/2000), it would be applied not only to the minister's salary, but to the total cost of operations, resulting in an allocation for campaign-intervention purposes that would still be a modest amount, but would be significantly more than the amount calculated under the pure minister salary method. By applying the

de minimis exception, like the statutory $\$ 2,000$ exception, reduces the degree to which the calculation methods maximize the government's interest in expenditure equity. For example, it would likely render sermon endorsement "free," since neither a minister nor any other employee is likely to spend more than five percent of his or her annual hours on whatever is necessary to prepare and make an endorsement. In addition, a taxpayer may ignore time spent on campaign activities by secretarial, clerical, support or other administrative personnel, so long as those hours are removed from both the numerator and denominator of the ratio. See Treas. Reg. $\S$ $1.162-28(\mathrm{~d})(3)$.

${ }^{134}$ See supra note 110 and accompanying text. 
ratio method to the total costs of operation, some attempt would be made to include "hidden" and capital costs in the allocation.

Therefore, as compared to the plain salary allocation performed above ${ }^{135}$ the ratio method, for example, does a better job of estimating the proper allocation. But an argument could be made that - even ignoring the de minimis exception - these allocation rules arguably fail to adequately provide a mechanism for estimating the portion of the organization's funds that have been used to support the campaignintervention activities. That is because they rely on an allocation of employees' time. If an organization's campaign-intervention activities were somehow capital-intensive - that is, if they made use of an organization's capital assets more than its employees' time - then these rules would under-estimate the amount of the organization's subsidy that was implicated in the campaign-intervention activity. As discussed above, an argument could be made that the most important "capital" asset of an organization making an endorsement is its reputation or credibility. An organization may have spent a significant amount of money over many years building the value of its credibility, and, as discussed above, it may have used tax-deductible contributions to do so. If the amount of time spent by employees fails to reflect the years spent building an organization's credibility, then the ratio method would arguably systematically undervalue campaign intervention activities by the organization.

\section{B. Allocation Using the Lump-Sum Safe Harbor Method}

If the Service wanted to attempt to take into account expenditures made for building an organization's credibility, it could promulgate guidance that stated that such costs must be taken into account if an organization wishes to endorse a candidate. It could then provide a simplification method that an organization could adopt in attempting to do so. Unfortunately, I have found no model for a simplifying method that could do that completely successfully. Nonetheless, I think that it is worth considering a largely arbitrary method that at least attempts to account for the funds expended to build an organization's credibility.

For example, in addition to providing simplifying safe-harbor methods like the ratio method, the Service could issue guidance that provided an alternative safe harbor that could be used if an organization's campaign-intervention activities included a 
communication of the organization's own view about a candidate (an express or implied endorsement). Under this safe harbor for endorsements (which I call the "Lump-Sum Safe Harbor" method), the Service could provide that it would treat as reasonable an allocation of the organization's resources to campaign-intervention at ten percent of the organization's total cost of operations (TCO) ${ }^{136}$ This largely arbitrary method for assessing the value of an organization's brand as it relates to its endorsement could be used as a supplement to a simplifying method like the ratio method. The ratio method is expressed by the formula:

(campaign-intervention labor hours/total labor hours X TCO) $+(3 d$ Party costs $)=$ Campaign Intervention Expenditures

The Lump Sum Safe Harbor method would simply add $10 \%$ of total cost of operations to the sum produced under the ratio method, so "campaign-intervention expenditures" for an organization that made an endorsement using the following formula:

(campaign-intervention labor hours/total labor hours X TCO) $+(3 d$ Party costs $)+($ TCO $X .1)=$ Campaign Intervention Expenditures

It should be emphasized that the Service would make clear that the ten percent lump sum estimation method is only a safe harbor, and if the organization has a more accurate, reasonable method for estimating the value of the organization's brand, then it could use that method. However, the costs of choosing an unreasonable method are dire: including both potential loss of exemption and imposition of severe excise taxes under section 4955 of the Code. ${ }^{137}$ Therefore, an organization would be well served to either use the safe harbor or seek a ruling from the Service approving its alternative method prior to using it.

This article has presented two possible options for allocation safe harbors. Both options could be crafted without de minimis safeharbors, making clear that the marginal cost theory is insufficient to account for campaign-intervention activities and that a cost allocation must include hard-to-identify (and potentially hidden) costs, such as the cost of attracting members, the cost of a meeting space, and the

\footnotetext{
${ }^{136}$ See Treas. Reg. 1.162-28(d)(4) (defining "total cost of operations").

137 See supra note 20.
} 
cost of supervising or training volunteers involved in the promulgating of the message. Under the first approach, simplification methods that are tied to employee time, like the ratio method, could be used to approximate the value of such hidden costs. Under the second approach, in the case of a communication that expresses a view of the candidates that can be attributed to the organization (an endorsement), the cost allocation would also have to involve some additional measure of the organization's credibility. ${ }^{138}$

\section{IS THE LUMP SUM SAFE HARBOR JUSTIFIED?}

Three compelling objections can be made to the Lump Sum Safe Harbor. This article neither endorses the adoption of the Lump Sum Safe Harbor nor opposes it. In the end, the Service should adopt some expenditure method, and the 1.162-28 model is probably adequate. But, if the Service were convinced that the 1.162-28 model insufficiently advances the goals of expenditure equity, then it would need to consider a solution like the Lump Sum Safe Harbor method. Objections include, first, the argument that expenditure equity does not demand that expenditures for "capital" investments, and especially "credibility," be taken into account, and so the Lump Sum Safe Harbor method actually distorts parity between taxpayers rather than equalizing their respective situations; second, that the Lump Sum Safe Harbor is just too arbitrary to solve any problem; and third, that (partially because of the impossibility of developing a valuation method to adequately take into account all of a charity's expenditures) the constitutional analysis is flawed, and the Service's current approach is constitutionally permissible.

\section{A. The Lump-Sum Safe Harbor Method Distorts Equitable Considerations}

The first objection is that the Lump Sum Safe Harbor does not advance the government's interest in expenditure equity or parity. As discussed above, the concept of expenditure equity is based on the idea that taxpayers should be treated as similarly as possible with

${ }^{138}$ If an endorsement were made by a non-501(c)(3) organization, attribution principles may apply to determine whether the value of the 501(c)(3) organization's credibility should be implicated. So, for example, an endorsement by a non-501(c)(3) organization affiliated with Nature Conservancy may include some of the value of the Nature Conservancy's "brand," even if the communication is formally made by the non-501(c)(3). 
respect their expenditures for campaign intervention. It was pointed out above that individual taxpayers cannot deduct the costs of their campaign-intervention activities. Similarly, under section 162(e), taxpayers that are engaged in a trade or business cannot deduct the costs of their campaign-intervention activities. Finally, nonprofits devoted to political activities may not receive tax-deductible contributions or use tax-free investment earnings for campaign intervention. So - the argument goes - charities should not be able to use tax-deductible contributions for their campaign-intervention activities.

The problem with this "parity" argument is that the three types of non-charity taxpayers are actually all treated slightly differently in ways that are material to the applicability of the Lump Sum Safe Harbor method ${ }^{139}$ First, while it is true that individual taxpayers may not deduct costs associated with campaign intervention, there is no method by which their "credibility" is considered a cost for these purposes. An individual taxpayer's endorsement of a candidate is "free," no matter how "credible" that taxpayer is, or how he built his credibility. If he is a minister of a 501(c)(3) church, and his credibility was built with tax-deductible funds, it is the same as if he is a private individual who built his credibility by purchasing advertisements extolling his virtues. Likewise, if the individual taxpayer is famous or has built her credibility through profit-seeking activities, her endorsement is similarly free, even though the expenditures made were probably deducted as ordinary and necessary business expenditures. Oprah Winfrey may be a salient example. Her endorsement is valuable in part because of the empire she has built around her own personality, an empire built with "pretax" funds, since they were likely incurred in the course of her business. The taxpayer who is most likely to be at a disadvantage in this context is a politician, who likely built his credibility using "post-tax" political contributions, although an incumbent has also used his office to build

139 See, e.g., Buckles, Reply, supra note 9, at 1109 ("were parity in politics really desired, sections 501(c)(3) entities that chose to expend funds to elect a candidate for public office would need to compensate the government at most only for that portion of the subsidy diverted to political ends"); and Galston, supra note 47, at 122-23 ("Since [permitting 501(c)(3) organizations to create affiliated 527 organizations] would have prevented money attributable to deductible charitable contributions from being used to support 527 groups, Congress's failure to allow 501(c)[(3)] organizations this option reveals that it must have been concerned with more than protecting the public fisc. Based upon the legislative history of $\$ 527$, it seems likely that the exclusion for 501(c)(3) groups derives from the underlying policy objective to keep charities themselves, and not just charities' money, out of political campaigns."). 
his credibility, again "for free." In this context, it is hard to see why charitable organizations should be treated to more stringent rules than individuals.

As for business taxpayers, we have already seen in $162(\mathrm{e})$, that there is both a generous statutory safe harbor $(\$ 2,000$ of non-thirdparty expenditures) and an absence of any express method for allocating expenditures for capital expenditures, much less "credibility" or "brand," to deny the deduction for a proper allocative share. Because there is no guidance in the area, it seems clear that business entities are not required to allocate "overhead" expenditures to campaign-intervention purposes to comply with the general denial of deduction for such expenditures under 162(e)(1)(B). This article has tried to avoid discussing the separate restrictions on expenditures by corporations under campaign-finance law, which require corporations to make certain campaign-intervention expenditures through a "PAC," using funds contributed on a non-deductible basis for that purpose ${ }^{140}$ But the rules that define such expenditures permit corporations to make all sorts of "overhead" expenditures for the benefit of their PACs, even from their "treasury" funds. Presumably, these expenditures are deductible under 162, since there is no required method for allocating overhead under the 1.162 Regulations.

Finally, while political organizations may not receive taxdeductible contributions, and may not use certain investment earnings for campaign-intervention without paying a tax on them, they may use certain limited tax-free earnings on campaign intervention (for example, from bingo).$^{141}$ More importantly, there is no guidance to suggest that a 501(c)(4) organization that chooses to make its campaign-intervention expenditures through a separate segregated fund under section 527 may not make certain expenditures for "overhead" outside of the fund. These expenditures could presumably be made using investment income earned on a tax-free basis. There is no hint anywhere that the Service would require such a taxpayer to pay for the use of its "credibility" out of its separate segregated fund.

If there is no concept of "credibility" reimbursement anywhere else in the Code, why should it appear only with regard to charities? Why should expenditure equity treat charities worse than all other taxpayers? The answer can only be that the government's interest in

${ }_{110}$ See, generally, FECA, 2 U.S.C. $\S \S 431-57$, specifically 2 U.S.C. $\S 441$ (b), 11 C.F.R. \$114.1(a), FEC, CAMPAIGN GUIDE FOR CORPORATIONS AND LABOR ORGANIZATIONS (2007).

${ }^{141}$ See I.R.C. $\$ 527(\mathrm{c})(3)$. 
expenditure equity does not need to result in exact parity between taxpayers. But the argument for taking into account the cost of building credibility, especially under a largely arbitrary method like the Lump Sum Safe Harbor method, is undercut by an examination of the treatment of endorsements by other taxpayers.

\section{B. The Lump Sum Safe Harbor Method is Arbitrary}

The second objection is that no theoretically sound method of valuing an organization's credibility has been found. The Lump Sum Safe Harbor method has two theoretical components: (1) the idea that a fixed percentage of total expenditures is an adequate measure of the subsidy received by an organization and (2) the idea that ten percent is the correct percentage. The second idea is completely arbitrary. There is no basis for choosing ten percent as the optimal fixed percentage of total expenditures and I know of no basis by which a theoretically defensible percentage could be selected.

As for the first claim, there is at least some justification. Since the goal of expenditure equity is to isolate expenditures made with taxdeductible funds, a measure such as total costs of operations does some rough justice to identifying which organizations have received more or less subsidy. For example, a church led by an unpaid preacher that gathered members by word of mouth and met in a public field of lilies would likely be able to engage in the most explicit kind of campaign intervention ("that Caesar is bad news") without any need to make use of an affiliate's non-deductible funds to pay for it. On the other hand, a televised ministry with a highly paid minister may have a significant amount of costs that would have to be shouldered by a non-501(c)(3) if it decides to engage in campaign-intervention activities. But this distinction between an all-volunteer organization and an expensive one correctly tracks the competing interests served by the Ban: to further expenditure equity while at the same time permitting organizations to engage in protected speech. The idea that organizations have spent an equal percentage of their funds on building their credibility is reasonable, at least as a simplification rubric.

\section{If There is No Compelling Valuation Method, Then The Service's Complete Ban is Constitutional}

Finally, some critics may argue that the Service's current approach is justified because the inadequacy of any proposed expenditure method to truly provide parity between 501(c)(3) 
organizations and other taxpayers supports the Service's approach of absolutely prohibiting 501(c)(3) organizations from engaging in campaign intervention. That is, if the very existence of an attribution of speech to a 501(c)(3) was found to involve an expenditure - and it was simply impossible to adequately measure or reimburse that expenditure - then that could conceivably justify an absolute ban on campaign-intervention speech by 501(c)(3) organizations. In effect, if the very possibility of a 501(c)(3) organization expressing its own views would produce an opportunity for abuse of the general statutory scheme surrounding campaign contributions, then some substantial burden may be justified.

This argument has been made before. In his dissent in League of Women Voters, Justice Rehnquist attacked the Court's application of the affiliate organization solution, arguing that,

The Court seems to believe that Congress actually subsidizes editorializing only if a station uses federal money specifically to cover the expenses that the Court believes can be isolated as editorializing expenses. But to me the Court's approach ignores economic reality. [The Corporation for Public Broadcasting's] unrestricted grants are used for salaries, training, equipment, promotion, etc.-financial expenditures which benefit all aspects of a station's programming, including management's editorials. Given the impossibility of compartmentalizing programming expenses in any meaningful way, it seems clear to me that the only effective means for preventing the use of public moneys to subsidize the airing of management's views is for Congress to ban a subsidized station from all on-the-air editorializing. ${ }^{142}$

In other words, if the "economic reality" is that there is no effective way to ensure that no government subsidy be used for the prohibited activity, then (according to Justice Rehnquist at least) the government can condition its funding on the organization agreeing not to engage in the prohibited activity at all. Or, in the case of permitting tax-deductible contributions, the government can condition the receipt of such contributions on the organization agreeing to refrain from engaging in campaign-intervention activities, even if the only alternative means for engaging in such activity is substantially burdensome.

${ }^{142}$ FCC v. League of Women Voters, 468 U.S. 364, 406 (Rehnquist, J., dissenting) (emphasis added). 
The final arbiter of these arguments, of course, will be a court. Scholars of the Constitution are in a much better position than I am to evaluate the relative merits of the arguments from the perspective of constitutional law. My goal in this article has been, rather, to explore the implications of the constitutional argument by thinking through the problems that would be faced by the Service if it (or Congress) embraced an expenditure paradigm as a way to avoid the constitutional problems. These problems are essentially accounting problems.

\section{CONCLUSION: WHY THE PROPOSED EXPENDITURE PARADIGM IS GOOD POLICY}

This article has argued that the problem with the Campaign Intervention Ban arises from competing policy goals. On the one hand is the constitutionally protected right of all persons - organizations included - to engage in political speech, including the communication of their views on the qualifications of candidates for public office. Competing with this constitutional imperative is the legitimate governmental interest in what $I$ have called expenditure equity - the desire to prevent the tax laws from providing a monetary benefit to some persons over others in their attempts to communicate their views about candidates. Without the Ban, the Code would permit individuals to deduct their contributions to organizations that then use those contributions to intervene in campaigns, thus creating a loophole in a statutory scheme designed to ensure that all campaignintervention expenditures are made with "after-tax" dollars.

The problem with the current Service interpretation of the Ban the attribution paradigm - is that it places an undue burden on certain organizations that wish to exercise their constitutionally protected rights. But, as I have argued herein, the Service does not have to pursue a constitutionally problematic enforcement strategy. ${ }^{143}$ A shift to an expenditure paradigm that successfully linked the

\footnotetext{
${ }^{143}$ After forcefully arguing that the Ban is unconstitutional, Laura Chisolm asks, "how can the constitutional dictates be reconciled with our instinctive feelings that section 501(c)(3) organizations ought not to be involved in partisan politics?" Chisolm, supra note 9, at 336-37. She answers: "The analysis that leads to the conclusion that total curtailment of political expression is not necessary to accomplish the legitimate purposes of tax exemption requires a careful exploration of alternatives. From that process there emerges a picture of an alternative arrangement that answers the constitutional objections; at the same time, we are reassured that less-restrictive measures respond quite well to our legitimate concerns about the purposes and integrity of the tax exemption." Id.
} 
subsidy provided under the Code to the prohibition contained in the Ban would advance the legitimate government interest in expenditure equity, without placing an undue burden on charities who want to pursue constitutionally protected activities like lending their moral and spiritual authority to the debate about candidates. ${ }^{144}$ This article has explored the complications that arise, however, when one takes seriously the attempt to fashion an expenditure paradigm. While those complications are real, it is my view that adopting an expenditure paradigm like the ones proposed herein - even with all their problems - would be better policy than continuing to attempt to enforce the Ban as it is currently interpreted by the Service.

First, adopting either of the proposals made herein would better balance the government's interests: expenditure equity on the one hand and free speech on the other. The current interpretation of the Ban is most likely unconstitutional, and for good reason. The attempt to silence charities (and especially churches) on a matter of such basic importance as the qualification of candidates for office is abhorrent to our constitutional scheme. The argument that the government has a right to control speech when it provides subsidies can go only so far. It cannot justify penalizing legitimate charities for communicating their views on candidates with completely unsubsidized funds. On the other hand, current proposals to permit the use of tax-deductible contributions for campaign-intervention speech in effect create a subsidy for such speech, potentially distorting the political process.

In addition to the primary goal of better balancing the government's interests, the adoption of an expenditure paradigm like the ones described herein has the benefit of being more theoretically defensible than the Service's current approach. In other words, simply by explaining the link between expenditures and the subsidy provided by section 170 of the Code, the government improves its situation. First, an enforcement paradigm that is theoretically justified is good in itself. Almost twenty-five years ago, Robert Cover argued that when

${ }^{144}$ It goes without saying that the restrictions that the government imposes on itself in regulating speech do not apply to the decisions religious (and other) communities make about their own pronouncements. I suspect that the majority of churches (and other charities) would not use their "cultural capital" to intervene in campaigns. The "moral authority" of many if not most of these organizations derives - in part - from the fact that they do not use it to try to influence voters, and these organizations would see a revolt of their members if they were to change that. But most is not all. Some religious communities (and other organizations) are committed to political agendas - even partisan political agendas - and they have a right under the law to be so committed, so long as they do not use the subsidies provided under the tax laws to advance their commitments. 
the government seeks to prevent communities from acting on their core values, it should make explicit the normative bases that compel the conflict. ${ }^{145}$ The fact that the law does more than persuade carries with it an obligation on the part of the government to make compelling the justifications for its laws. Thus, when the government explains why its interpretations of its laws are theoretically justified, it advances the goal of good governance.

In addition to being an end in itself, adopting an expenditure paradigm and explaining it may well improve voluntary compliance by charities. As Anne Carroll has pointed out, "the churches and their leaders can respond to critics of their [campaign intervention] conduct with powerful moral, theological, and historical arguments to which the simplistic formulations of the federal tax authorities supply no ready answers." ${ }^{146}$ The constitutional principles contained in the First Amendment reflect an underlying normative framework, by which people in communities (especially religious communities) may view the attempts by the Service to utterly silence them on electoral issues to be illegitimate. Once the Service withdraws its assault on political speech by charities and replaces it with an attempt to force them to provide an adequate accounting of the subsidy provided by the government, charities may well be convinced that such an accounting is legitimate and actually do it. The expenditure paradigm asks the Service and 501(c)(3) organizations to think about how much their campaign-intervention speech costs, so that charities may use funds donated for such a purpose without the benefit of tax-deduction. Once the topic has switched to a technical issue - cost - it seems unlikely (or at least less likely) that a charity would view the government's interest as conflicting with its core values. The government is not saying to a charity, "be silent on such issues." It is merely saying, "sit down and count the cost." ${ }^{147}$ It is only logical that a charity would be more likely to voluntarily comply with such a law.

Even if charities are not convinced that such an accounting is legitimate, having a theoretically justifiable enforcement paradigm may help the Service. Freed from its fear that the Ban is unconstitutional or contrary to important values, the Service may be able to enforce its new expenditure paradigm more aggressively. Thus, it may better regulate the behavior than the current situation in which

${ }_{145}$ Robert Cover, The Supreme Court, 1982 Term: Foreword: Nomos and Narrative, 97 HARV. L. REV. 4 (1983).

${ }^{146}$ Carroll, supra note 4, at 226.

${ }^{147}$ Luke 14:28 (Darby Translation). 
the Service promulgates an expansive enforcement paradigm, but does not aggressively enforce it. As is apparent from the Service's inconsistent enforcement of the law over the past several decades, a solution that could advance the government's legitimate interests while promoting compliance would be a significant improvement over the current regulatory paradigm.

Finally, notification of the existence of a reimbursement for campaign intervention could be required, either under campaignfinance laws or under the tax code. There is nothing inconsistent with expenditure equity or the Constitution in requiring expenditures for campaign intervention to be disclosed in any number of ways. As campaign-finance law has long recognized, disclosure is a powerful tool in the protection of the integrity of the electoral system, especially with the advent of the internet.

The majority of these benefits would arguably accrue whether the Service adopted a relatively lax standard, such as one modeled on the safe-harbor methods provided in 1.162-28, or a more stringent standard, such as the Lump-Sum Safe Harbor method. The first option is more easily defended as theoretically sound, which is, after all, one of the most important goals of the proposed reform. But it arguably undervalues campaign-intervention expenditures by a 501(c)(3) organization, and therefore arguably under-serves the interests of expenditure equity. The second method has the strength of attempting to take into account all relevant campaign-intervention expenses. But it has the weakness of being premised on a theoretical basis that is arguable at best, and on an implementation that is largely arbitrary. Both methods in effect turn a liberty issue into a valuation issue, and may thereby have the potential to build consensus either for increased voluntary compliance or increased aggressive enforcement. The proper role of charities - and especially churches - in politics is a subject worthy of debate, of course. But the federal government, especially as it acts through its revenue gathering agency, should limit itself to considering how to avoid subsidizing such speech through the Code. 